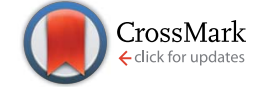

Cite this: RSC Adv., 2017, 7, 8866
Received 21st October 2016 Accepted 11th January 2017

DOI: $10.1039 / c 6 r a 25590 f$

www.rsc.org/advances

\section{Synthesis and biological evaluation of terminal functionalized thiourea-containing dipeptides as antitumor agents $\uparrow$}

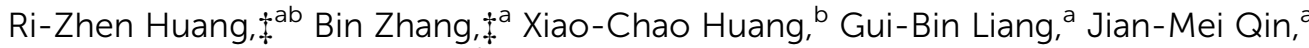 \\ Ying-Ming Pan, ${ }^{a}$ Zhi-Xin Liao*b and Heng-Shan Wang ${ }^{\star a}$
}

\begin{abstract}
A series of antitumor agents based on terminal functionalized dipeptide derivatives containing the thiourea moiety were synthesized and evaluated for antiproliferative activity using a panel of cancer cell lines, and the effects and mechanism of apoptosis induction were determined. These compounds exhibited significant selectivity to different cancer cell lines with $\mathrm{IC}_{50}$ values at micromolar concentrations. In particular, compound I-11 appeared to be the most potent compound, with an $\mathrm{IC}_{50}=4.85 \pm 1.44 \mu \mathrm{M}$ against the $\mathrm{NCl}-\mathrm{H} 460$ cell line, at least partly, by the induction of apoptosis. Mechanistically, compound I-11 induced the activation of caspase-12 and CHOP, which triggered apoptotic signalling via the ROSdependent endoplasmic reticulum pathway and arrested the cell cycle at the $S$ phase. Thus, we concluded that dipeptide derivatives containing the thiourea moiety terminally functionalized by electron-withdrawing substituents may be potential antitumor agents for further investigation.
\end{abstract}

\section{Introduction}

Peptides are among the most versatile bioactive molecules and play crucial roles in the human body and other organisms. ${ }^{1}$ Because of their good solubility, permeability and bioavailability, many peptide hormones and analogous short peptides exert their action by binding to membrane receptors, ${ }^{2,3}$ or possess signaling and regulatory functions. ${ }^{4}$ Accordingly, the potential applications of these peptide-like structures are legion and become immediately apparent. Recently, several peptidebased derivatives have been in clinical trials, including bortezomib, $^{5}$ carfilzomib, ${ }^{6}$ DLS-10 (ref. 7) and ixazomib ${ }^{8}$ (Fig. 1). Encouraged by these research results, our interest in investigating peptide-based drugs for their potential therapeutic effects has recently spurred us to examine the influences of dipeptide derivatives on antitumor properties.

Previous work has indicated that dipeptides and their derivatives, in addition to enzyme inhibitors or drug carriers, exhibit a wide spectrum of important bioactivities such as antimicrobial, neuroprotective, antiviral and anticancer activities. $^{9-11}$ In particular, anticancer peptides have shown relevant

${ }^{a}$ State Key Laboratory for the Chemistry and Molecular Engineering of Medicinal Resources (Ministry of Education of China), School of Chemistry and Pharmaceutical Sciences of Guangxi Normal University, Yucai Road 15, Guilin 541004, Guangxi, PR China. E-mail: whengshan@163.com

${ }^{b}$ Pharmaceutical Research Center and School of Chemistry and Chemical Engineering, Southeast University, Nanjing 211189, China. E-mail: zxliao@seu.edu.cn

$\dagger$ Electronic supplementary information (ESI) available. See DOI: $10.1039 /$ c6ra25590f

$\$$ These authors contributed equally to this work. potency since they exhibit cancer selective toxicity while avoiding the shortcomings of the conventional chemotherapy. ${ }^{\mathbf{1 2}}$ Modern studies have also indicated that dipeptides as well as their analogs exhibit anticancer activity in many human cancer cells such as colon, gastric, cervical and breast cancer cells. ${ }^{\mathbf{1 3 - 1 6}}$ However, most of the natural peptides consist of the $\mathrm{L}$-form $\alpha$ amino acids and due to the ubiquitous prevalence of peptidases, they exhibit limited biostability, and consequently, low bioavailability. ${ }^{17}$ The inability to cross epithelial layers, including the blood-brain barrier, side effects and drug resistance remain the major clinical challenges. Due to these limitations, the development of pseudopeptides could lead to many pharmacokinetic and pharmacodynamic advantages. This strategy can be realized by introducing unnatural amino acids instead of natural residues into the peptide framework, or by the introduction of a non-peptidic scaffold into the peptidic backbone, to lock a defined conformation of the peptide. ${ }^{\mathbf{1 8 , 1 9}}$ These novel compounds provide new perspectives in drug design by providing an entire range of highly specific and nontoxic pharmaceuticals. Several non-peptidic skeletons have been thus conjugated with peptides, and such analogs as conjugates of paclitaxel, doxorubicin and daunorubicin with an amino acid or peptides have demonstrated increased and more selective anticancer activity than the drugs themselves. ${ }^{20-26}$

Among the anti-tumor drugs discovered in recent years, thiourea derivatives ${ }^{27,28}$ possess potent anticancer properties. Thiourea derivatives display a wide range of biological activity including antibacterial, anti-fungal, antiviral, anthelmintic, antituberculosis, and plant growth regulator properties. ${ }^{29-32}$ In addition to increased stability, the incorporation of a thiourea 

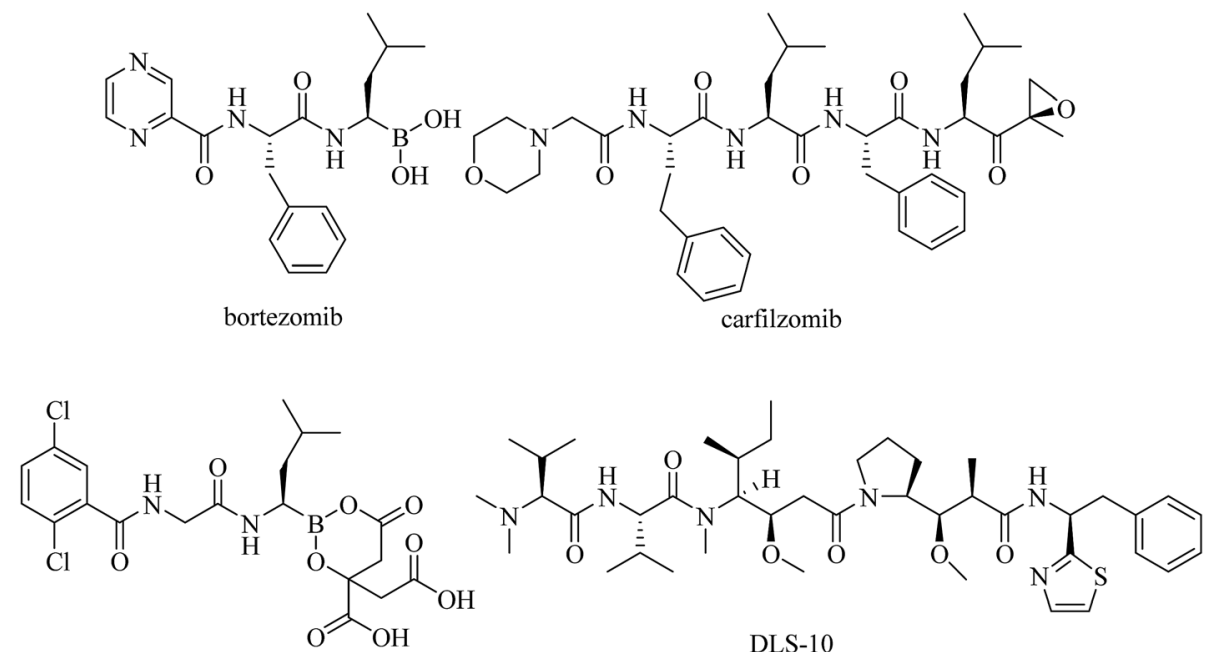

ixazomib

DLS-10

Fig. 1 Chemical structures of peptide-based derivatives for clinical use.

moiety into the peptide sequence also provides access to additional binding interactions within the transition state conformation of the enzyme/substrate complex. ${ }^{33,34}$ Thiourea could strongly enhance blocking, since sulfur is the weaker hydrogen bond acceptor as compared to the amide carbonyl oxygen, and simultaneously enhance hydrogen-bonding due to the bidentate binding mode of the more acidic thiourea protons. ${ }^{35,36}$ Herein, we designed and synthesized a series of dipeptide thiourea derivatives as antitumor drugs. Their in vitro cytotoxicities against five selected tumor cell lines were evaluated. Moreover, the molecular mechanism of apoptosis in NCI-H460 cells by the representative target compound I-11 was also investigated.

\section{Results and discussion}

\subsection{Chemistry}

The general procedures for the synthesis of functionalized dipeptide thioureas are shown in Scheme 1. First, Boc-amide and aniline derivatives underwent acylation and deprotection, and each amino acid was sequentially coupled to the peptide chain from the C- to N-terminus in the presence of HOBT, EDCI and $\mathrm{Et}_{3} \mathrm{~N}$. After obtaining the free amine dipeptide $\mathbf{H}$ by the removal of the protective group, target compounds I were synthesized by the condensation of phenylisothiocyanate, according to a previously published report, ${ }^{37}$ with $\mathbf{H}$ in DCM at room temperature. The structures of target compounds I were then confirmed by ${ }^{1} \mathrm{H}$ NMR, ${ }^{13} \mathrm{C}$ NMR and high resolution mass spectrometry (HRMS).

\subsection{Biology activity}

2.2.1 Cytotoxicity test. The in vitro cytotoxicity of the synthesized compounds was evaluated by the methylthiazol tetrazolium (MTT) assay in a panel of five human cancer cell lines, including MGC-803 human gastric cancer cells, NCI-H460 human lung cancer cells, HepG-2 human liver cancer cells,
Hct-116 human colon tumor cells, and SKOV-3 human ovarian cancer cells. The commercial anticancer drugs 5-fluorouracil (5-FU) and ubenimex (Ube) were positive controls. The assay results are shown in Table 1, where we see that most of the test compounds exhibited moderate to high inhibitory activity against the tested tumor cell lines, indicating that the introduction of the thiourea moiety on the dipeptide could improve anti-tumor activity. Compounds I-10, I-11 and I-32 showed good inhibitory activity for all the tested carcinoma cell lines. Compound I-9 showed strong inhibitory activity selectivity for MGC-803, as well as NCI-H460; I-31 showed selectivity for NCIH40, and I-25 showed selectivity for MGC-803. The others also showed good inhibitory activity, except I-8, I-16, I-17, I-30, I-33, I-34, for the tested carcinoma cell lines. In particular, compound I-11 showed noteworthy anti-cancer activity in vitro, with $\mathrm{IC}_{50}$ value of $4.85 \mu \mathrm{M}$ against NCI-H460. The results revealed that the analogs $\mathbf{I}-\mathbf{1 1}, \mathbf{I}-\mathbf{2 5}, \mathbf{I}-\mathbf{3 1}$ and $\mathbf{I}-\mathbf{3 2}$, obtained by inserting the trifluoromethyl or halogen moiety in positions $\mathrm{R}_{1}$ and $\mathrm{R}_{2}$ of the benzene ring, significantly increased antiproliferative potencies. For example, compound $\mathbf{I}-25$, with $\mathrm{IC}_{50}$ value of $9.13 \mu \mathrm{M}$, was more active than derivatives $\mathbf{I}-24$ and $\mathbf{I}-26$, and undoubtedly emerged as one of the most active compounds within this subset, thus suggesting that the insertion of electron-withdrawing groups in positions $R_{1}$ and $R_{2}$ may have resulted in certain steric electronic properties that enhanced lipophilicity and the ability to penetrate the cellular membrane, leading to an increased antiproliferative effect. On the other hand, the presence of a weakly electron-withdrawing substituent in positions $R_{1}$ and $R_{2}$ is harmful to the antiproliferative effect: the derivatives $\mathbf{I}-\mathbf{3 3}$ and $\mathbf{I}-\mathbf{3 4}$ were not active against the tested cell lines. A slight beneficial effect was also observed with the modifications of the $R_{3}$ and $R_{4}$ positions: the derivative $\mathbf{I}-\mathbf{1 1}$ was more active than $\mathbf{I - 3 2}$. It is also important to note that the $\mathbf{R}_{\mathbf{1}}$ and $R_{2}$ substitutions seem more important for cytotoxicity than $\mathrm{R}_{3}$ or $\mathrm{R}_{4}$ substitutions, since the variation of $\mathrm{R}_{3}$ or $\mathrm{R}_{4}$ slightly changed the potency. These interesting results may indicate 


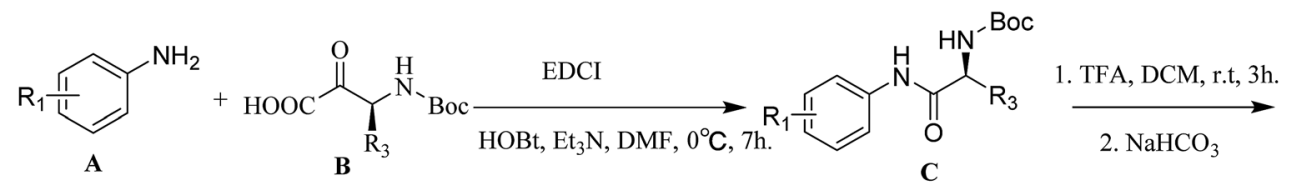

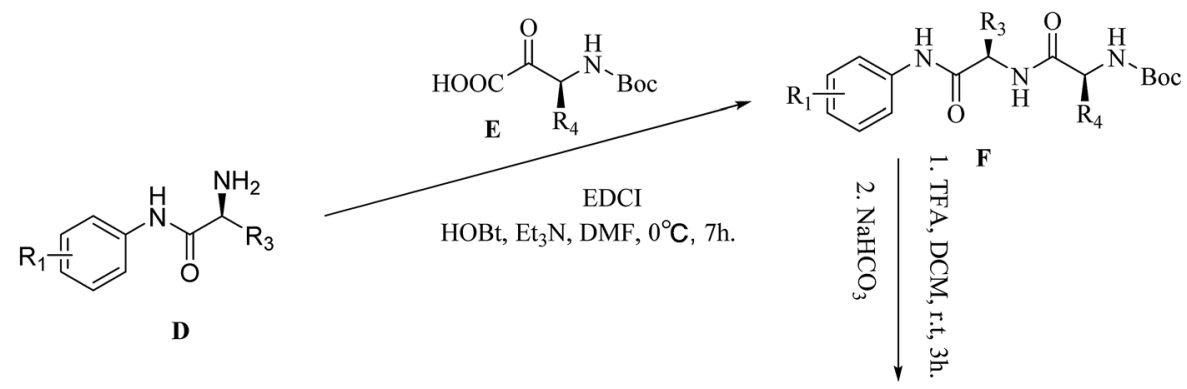<smiles>[R2]c1ccc(NC(=O)C([R3])NC(=O)C([R3])NC(=S)Nc2ccc([R2])cc2)cc1</smiles>

I-1 $\mathrm{R}_{1}=3,6-\mathrm{CH}_{3} \mathrm{O} ; \mathrm{R}_{2}=3-\mathrm{O}_{2} \mathrm{~N} ; \mathrm{R}_{3}=\mathrm{CH}_{2}$-phenyl; $\mathrm{R}_{4}=$ secbutyl I-2 $\mathrm{R}_{1}=3,5-\mathrm{CH}_{3} \mathrm{O} ; \mathrm{R}_{2}=3-\mathrm{O}_{2} \mathrm{~N} ; \mathrm{R}_{3}=\mathrm{CH}_{2}$-phenyl; $\mathrm{R}_{4}=$ secbutyl I-3 $\mathrm{R}_{1}=3,5-\mathrm{CH}_{3} ; \quad \mathrm{R}_{2}=3-\mathrm{O}_{2} \mathrm{~N} ; \mathrm{R}_{3}=\mathrm{CH}_{2}$-phenyl; $\mathrm{R}_{4}=$ secbutyl I-4 $\mathrm{R}_{1}=3,4,5-\mathrm{CH}_{3} \mathrm{O} ; \mathrm{R}_{2}=3-\mathrm{O}_{2} \mathrm{~N} ; \mathrm{R}_{3}=\mathrm{CH}_{2}$-phenyl; $\mathrm{R}_{4}=$ secbutyl I-5 $\mathrm{R}_{1}=4-\mathrm{CH}_{3} \mathrm{O} ; \mathrm{R}_{2}=3-\mathrm{Cl} ; \mathrm{R}_{3}=\mathrm{CH}_{2}$-phenyl; $\mathrm{R}_{4}=$ secbutyl I-6 $\mathrm{R}_{1}=4-\mathrm{CH}_{3} \mathrm{O} ; \mathrm{R}_{2}=4-\mathrm{CH}_{3}-3-\mathrm{Cl} ; \mathrm{R}_{3}=\mathrm{CH}_{2}$-phenyl; $\mathrm{R}_{4}=$ secbutyl I-7 $\mathrm{R}_{1}=3,4,5-\mathrm{CH}_{3} \mathrm{O} ; \mathrm{R}_{2}=2,4-\mathrm{Br} ; \mathrm{R}_{3}=\mathrm{CH}_{2}$-phenyl; $\mathrm{R}_{4}=$ secbutyl I-8 $\mathrm{R}_{1}=4-\mathrm{CH}_{3} \mathrm{O} ; \mathrm{R}_{2}=1$-naphthalene; $\mathrm{R}_{3}=\mathrm{CH}_{2}$-phenyl; $\mathrm{R}_{4}=$ secbutyl I-9 $\mathrm{R}_{1}=4-\mathrm{F}-3-\mathrm{Cl} ; \mathrm{R}_{2}=5$-F; $\mathrm{R}_{3}=\mathrm{CH}_{2}$-phenyl; $\mathrm{R}_{4}=\mathrm{CH}_{2}$-phenyl I-10 R $\mathrm{R}_{1}=3-\mathrm{CF}_{3} ; \mathrm{R}_{2}=4,5-\mathrm{Cl} ; \mathrm{R}_{3}=\mathrm{CH}_{2}$-phenyl; $\mathrm{R}_{4}=\mathrm{CH}_{2}$-phenyl I-11 $\mathrm{R}_{1}=3-\mathrm{CF}_{3} ; \mathrm{R}_{2}=5-\mathrm{CF}_{3} ; \mathrm{R}_{3}=\mathrm{CH}_{2}$-phenyl; $\mathrm{R}_{4}=\mathrm{CH}_{2}$-phenyl I-12 $\mathrm{R}_{1}=2-\mathrm{CH}_{3} ; \mathrm{R}_{2}=4,5-\mathrm{Cl} ; \mathrm{R}_{3}=\mathrm{CH}_{2}$-phenyl; $\mathrm{R}_{4}=\mathrm{CH}_{2}$-phenyl I-13 $\mathrm{R}_{1}=3$-F; $\mathrm{R}_{2}=5-\mathrm{CF}_{3} ; \mathrm{R}_{3}=\mathrm{CH}_{2}$-phenyl; $\mathrm{R}_{4}=\mathrm{CH}_{2}$-phenyl I-14 $\mathrm{R}_{1}=3$-F; $\mathrm{R}_{2}=4,5-\mathrm{Cl} ; \mathrm{R}_{3}=\mathrm{CH}_{2}$-phenyl; $\mathrm{R}_{4}=\mathrm{CH}_{2}$-phenyl I-15 $\mathrm{R}_{1}=3$-F; $\mathrm{R}_{2}=5-\mathrm{OCH}_{3} ; \mathrm{R}_{3}=\mathrm{CH}_{2}$-phenyl; $\mathrm{R}_{4}=\mathrm{CH}_{2}$-phenyl I-16 $\mathrm{R}_{1}=3,5-\mathrm{CH}_{3} ; \mathrm{R}_{2}=5$ - $\mathrm{Cl} ; \mathrm{R}_{3}=\mathrm{CH}_{2}$-phenyl; $\mathrm{R}_{4}=\mathrm{CH}_{2}$-phenyl I-17 $\mathrm{R}_{1}=3,5-\mathrm{CH}_{3} ; \mathrm{R}_{2}=4-\mathrm{Cl} ; \mathrm{R}_{3}=\mathrm{CH}_{2}$-phenyl; $\mathrm{R}_{4}=\mathrm{CH}_{2}$-phenyl I-18 $\mathrm{R}_{1}=3,5-\mathrm{CH}_{3} ; \mathrm{R}_{2}=4-\mathrm{F}-5-\mathrm{Cl} ; \mathrm{R}_{3}=\mathrm{CH}_{2}$-phenyl; $\mathrm{R}_{4}=\mathrm{CH}_{2}$-phenyl
I-19 $\mathrm{R}_{1}=3-\mathrm{CF}_{3} ; \mathrm{R}_{2}=5$ - $\mathrm{Cl} ; \mathrm{R}_{3}=\mathrm{CH}_{2}$-phenyl; $\mathrm{R}_{4}=\mathrm{CH}_{2}$-phenyl

I-20 $\mathrm{R}_{1}=4-\mathrm{Br} ; \mathrm{R}_{2}=5$ - $\mathrm{Br} ; \mathrm{R}_{3}=$ secbutyl; $\mathrm{R}_{4}=$ isopropyl

I-21 $\mathrm{R}_{1}=4-\mathrm{Br} ; \mathrm{R}_{2}=4,5-\mathrm{Cl} ; \mathrm{R}_{3}=$ secbutyl; $\mathrm{R}_{4}=$ isopropyl

I-22 $\mathrm{R}_{1}=4-\mathrm{Br} ; \mathrm{R}_{2}=2-\mathrm{F} ; \mathrm{R}_{3}=$ secbutyl; $\mathrm{R}_{4}=$ isopropyl

I-23 $\mathrm{R}_{1}=4-\mathrm{Br} ; \mathrm{R}_{2}=4-\mathrm{F} ; \mathrm{R}_{3}=$ secbutyl; $\mathrm{R}_{4}=$ isopropyl

I-24 $\mathrm{R}_{1}=4-\mathrm{F}-3-\mathrm{Cl} ; \mathrm{R}_{2}=1$-naphthalene; $\mathrm{R}_{3}=$ secbutyl; $\mathrm{R}_{4}=$ isopropyl

I-25 $\mathrm{R}_{1}=4-\mathrm{F}-3-\mathrm{Cl} ; \mathrm{R}_{2}=3,4-\mathrm{Cl} ; \mathrm{R}_{3}=$ secbutyl; $\mathrm{R}_{4}=$ isopropyl

I I-26 $\mathrm{R}_{1}=3-\mathrm{Cl}-4-\mathrm{F} ; \mathrm{R}_{2}=4-\mathrm{CH}_{3}-3-\mathrm{Cl} ; \mathrm{R}_{3}=$ secbutyl; $\mathrm{R}_{4}=$ isopropyl

I-27 $\mathrm{R}_{1}=4-\mathrm{F}-3-\mathrm{Cl} ; \mathrm{R}_{2}=4-\mathrm{OCH}_{3} ; \mathrm{R}_{3}=$ secbutyl; $\mathrm{R}_{4}=$ isopropyl

I-28 $\mathrm{R}_{1}=3,6-\mathrm{OCH}_{3} ; \mathrm{R}_{2}=3-\mathrm{NO}_{2} ; \mathrm{R}_{3}=$ secbutyl; $\mathrm{R}_{4}=$ isopropyl

I-29 $\mathrm{R}_{1}=4-\mathrm{CH}_{3}-3-\mathrm{Cl} ; \mathrm{R}_{2}=3-\mathrm{NO}_{2} ; \mathrm{R}_{3}=$ secbutyl; $\mathrm{R}_{4}=$ isopropyl

I-30 $\mathrm{R}_{1}=3-\mathrm{Cl} ; \mathrm{R}_{2}=3,4,5-\mathrm{CH}_{3} ; \mathrm{R}_{3}=$ isopropyl; $\mathrm{R}_{4}=$ secbutyl

I-31 $\mathrm{R}_{1}=3-\mathrm{Cl} ; \mathrm{R}_{2}=3,4-\mathrm{Cl} ; \mathrm{R}_{3}=$ isopropyl; $\mathrm{R}_{4}=$ secbutyl

I-32 $\mathrm{R}_{1}=3-\mathrm{Cl} ; \mathrm{R}_{2}=4-\mathrm{F}-5-\mathrm{CF}_{3} ; \mathrm{R}_{3}=$ isopropyl; $\mathrm{R}_{4}=$ secbutyl

I-33 $\mathrm{R}_{1}=3-\mathrm{CH}_{3} ; \mathrm{R}_{2}=3,4-\mathrm{CH}_{3} ; \mathrm{R}_{3}=$ isopropyl; $\mathrm{R}_{4}=$ secbutyl

I-34 $\mathrm{R}_{1}=3-\mathrm{CH}_{3} ; \mathrm{R}_{2}=3-\mathrm{OCH}_{3} ; \mathrm{R}_{3}=$ isopropyl; $\mathrm{R}_{4}=$ secbutyl

I-35 $\mathrm{R}_{1}=3-\mathrm{CH}_{3} ; \mathrm{R}_{2}=4-\mathrm{Cl} ; \mathrm{R}_{3}=$ isopropyl; $\mathrm{R}_{4}=$ secbutyl

I-36 $\mathrm{R}_{1}=3,4-\mathrm{CH}_{3} ; \mathrm{R}_{2}=3-\mathrm{NO}_{2} ; \mathrm{R}_{3}=$ isopropyl; $\mathrm{R}_{4}=$ secbutyl

Scheme 1 General synthetic route for compound I.

that these compounds exert their antitumor activities by targeting different protein targets or signal pathways. The presence of a bulky group in position $R_{3}$ and $R_{4}$ seems to be associated with a general increase in activity. In addition, the inhibition activities of compounds I against HUVEC normal cell lines were also estimated in Table 1 . The results indicated that the cytotoxicity of most of the compounds against cancer cells was much higher than the HUVEC normal cells, as compared to 5-FU and Ube, making them good candidates for anti-tumor drugs.

2.2.2 Cell cycle analysis. To determine the possible role of cell cycle arrest in dipeptide thiourea derivative-induced growth inhibition, NCI-H460 cells were treated with different concentrations of compound I-11. Cell cycle distribution was investigated by flow cytometric analysis following staining of DNA with propidium iodide (PI). After treatment with compound I-11 at different concentrations for $48 \mathrm{~h}$, it was observed that G1 phase cells gradually decreased and G2 phase cells did not change significantly, while S phase cells, compared with the control cells, gradually increased (Fig. 2 and 3). These results suggest that target compound I-11 mainly arrested NCI$\mathrm{H} 460$ cells in the $\mathrm{S}$ phase.

2.2.3 Compound I-11 induces apoptosis in NCI-H460 cells. In order to confirm whether I-11-induced reduction in cell viability was responsible for the induction of apoptosis, NCIH460 cells were co-stained with PI and Annexin-V FITC, and 
Table $1 \quad I C_{50}$ values $(\mu M)$ of functionalized dipeptide thiourea derivatives I towards five selected tumor cell lines and normal cell lines, for $48 \mathrm{~h}$

\begin{tabular}{|c|c|c|c|c|c|c|}
\hline \multirow[b]{2}{*}{ Compd } & \multicolumn{6}{|l|}{$\mathrm{IC}_{50}{ }^{a}(\mu \mathrm{M})$} \\
\hline & MGC-803 & NCI-H460 & Hct-116 & HepG-2 & SKOV-3 & HUVEC \\
\hline I-1 & $25.82 \pm 1.12$ & $23.11 \pm 1.22$ & $29.34 \pm 1.07$ & $27.16 \pm 1.16$ & $24.58 \pm 0.91$ & $>50$ \\
\hline I-2 & $24.51 \pm 0.83$ & $24.32 \pm 1.29$ & $26.17 \pm 1.01$ & $29.05 \pm 0.96$ & $29.96 \pm 0.87$ & $>50$ \\
\hline I-3 & $40.01 \pm 0.86$ & $38.37 \pm 0.93$ & $39.25 \pm 1.14$ & $41.27 \pm 1.02$ & $44.32 \pm 1.11$ & $>50$ \\
\hline I-4 & $20.85 \pm 1.06$ & $21.39 \pm 0.99$ & $21.06 \pm 0.98$ & $26.79 \pm 1.10$ & $28.28 \pm 0.89$ & $>50$ \\
\hline I-5 & $30.43 \pm 1.00$ & $31.20 \pm 1.04$ & $27.77 \pm 0.94$ & $34.57 \pm 0.85$ & $30.99 \pm 1.35$ & $>50$ \\
\hline I-6 & $38.95 \pm 0.71$ & $39.48 \pm 1.25$ & $38.62 \pm 0.68$ & $42.07 \pm 1.18$ & $39.24 \pm 0.49$ & $>50$ \\
\hline I-7 & $26.38 \pm 1.21$ & $25.41 \pm 1.33$ & $30.17 \pm 0.90$ & $30.95 \pm 1.23$ & $31.84 \pm 0.75$ & $>50$ \\
\hline I-8 & $>50$ & $>50$ & $>50$ & $>50$ & $>50$ & $>50$ \\
\hline I-9 & $8.92 \pm 1.02$ & $9.55 \pm 0.46$ & $10.70 \pm 0.85$ & $12.31 \pm 1.13$ & $13.60 \pm 1.08$ & $>50$ \\
\hline I-10 & $7.49 \pm 1.06$ & $13.06 \pm 1.19$ & $9.13 \pm 1.11$ & $13.70 \pm 0.92$ & $10.36 \pm 1.04$ & $>50$ \\
\hline I-11 & $8.26 \pm 1.27$ & $4.85 \pm 1.44$ & $8.92 \pm 1.26$ & $10.88 \pm 1.05$ & $10.86 \pm 1.14$ & $>50$ \\
\hline I-12 & $33.05 \pm 1.05$ & $30.29 \pm 1.42$ & $38.47 \pm 0.84$ & $37.21 \pm 1.15$ & $>50$ & $>50$ \\
\hline I-13 & $12.53 \pm 1.21$ & $14.65 \pm 0.74$ & $19.82 \pm 0.89$ & $13.82 \pm 1.03$ & $23.27 \pm 1.32$ & $>50$ \\
\hline I-14 & $12.27 \pm 1.18$ & $17.89 \pm 1.13$ & $22.51 \pm 0.74$ & $21.28 \pm 0.76$ & $21.24 \pm 1.24$ & $>50$ \\
\hline I-15 & $30.45 \pm 1.28$ & $41.29 \pm 1.15$ & $36.71 \pm 0.64$ & $33.22 \pm 1.31$ & $42.36 \pm 0.82$ & $>50$ \\
\hline I-16 & $>50$ & $>50$ & $>50$ & $>50$ & $>50$ & $>50$ \\
\hline I-17 & $>50$ & $>50$ & $>50$ & $>50$ & $>50$ & $>50$ \\
\hline I-18 & $38.21 \pm 1.09$ & $41.89 \pm 0.97$ & $46.61 \pm 1.03$ & $38.95 \pm 1.19$ & $42.48 \pm 0.99$ & $>50$ \\
\hline I-19 & $16.73 \pm 0.86$ & $14.95 \pm 0.59$ & $16.43 \pm 1.08$ & $20.13 \pm 1.16$ & $15.98 \pm 1.51$ & $>50$ \\
\hline I-20 & $18.79 \pm 1.14$ & $18.51 \pm 0.88$ & $20.83 \pm 0.98$ & $24.45 \pm 1.27$ & $22.78 \pm 0.87$ & $>50$ \\
\hline I-21 & $16.47 \pm 0.97$ & $15.63 \pm 0.58$ & $20.73 \pm 1.21$ & $19.44 \pm 0.95$ & $20.81 \pm 1.47$ & $>50$ \\
\hline I-22 & $17.15 \pm 1.26$ & $17.31 \pm 1.31$ & $19.86 \pm 1.29$ & $21.86 \pm 1.18$ & $19.35 \pm 1.53$ & $>50$ \\
\hline I-23 & $17.52 \pm 1.22$ & $17.66 \pm 1.23$ & $18.59 \pm 1.34$ & $21.05 \pm 1.28$ & $20.24 \pm 1.45$ & $>50$ \\
\hline I-24 & $37.98 \pm 1.03$ & $40.82 \pm 1.79$ & $41.55 \pm 1.25$ & $40.79 \pm 0.71$ & $46.43 \pm 1.33$ & $>50$ \\
\hline I-25 & $9.13 \pm 1.09$ & $10.62 \pm 1.14$ & $12.74 \pm 1.17$ & $14.32 \pm 1.20$ & $13.82 \pm 1.02$ & $>50$ \\
\hline I-26 & $35.48 \pm 0.83$ & $31.67 \pm 1.49$ & $34.83 \pm 1.13$ & $36.24 \pm 1.21$ & $39.40 \pm 1.36$ & $>50$ \\
\hline I-27 & $29.22 \pm 0.76$ & $28.80 \pm 1.37$ & $30.76 \pm 1.04$ & $31.81 \pm 1.26$ & $32.49 \pm 0.62$ & $>50$ \\
\hline I-28 & $34.37 \pm 1.09$ & $32.46 \pm 1.06$ & $37.63 \pm 1.16$ & $38.24 \pm 0.91$ & $37.38 \pm 1.20$ & $>50$ \\
\hline I-29 & $28.25 \pm 1.11$ & $29.58 \pm 1.28$ & $30.48 \pm 0.78$ & $31.65 \pm 0.88$ & $32.10 \pm 1.51$ & $>50$ \\
\hline I-30 & $>50$ & $>50$ & $>50$ & $>50$ & $>50$ & $>50$ \\
\hline I-31 & $13.75 \pm 1.23$ & $9.93 \pm 1.36$ & $11.59 \pm 0.94$ & $15.09 \pm 1.17$ & $10.26 \pm 0.96$ & $>50$ \\
\hline I-32 & $8.79 \pm 0.77$ & $7.93 \pm 1.05$ & $13.78 \pm 1.15$ & $10.16 \pm 0.84$ & $11.62 \pm 1.08$ & $>50$ \\
\hline I-33 & $>50$ & $>50$ & $>50$ & $>50$ & $>50$ & $>50$ \\
\hline I-34 & $>50$ & $>50$ & $>50$ & $>50$ & $>50$ & $>50$ \\
\hline I-35 & $41.65 \pm 1.02$ & $39.07 \pm 1.34$ & $42.69 \pm 0.36$ & $41.78 \pm 1.04$ & $40.57 \pm 0.61$ & $>50$ \\
\hline $\mathrm{I}-36$ & $42.93 \pm 1.36$ & $44.86 \pm 1.17$ & $>50$ & $>50$ & $>50$ & $>50$ \\
\hline 5-FU & $46.92 \pm 2.03$ & $44.05 \pm 0.64$ & $23.50 \pm 2.34$ & $30.98 \pm 0.73$ & $27.23 \pm 0.16$ & $56.00 \pm 1.45$ \\
\hline Ube & $>50$ & $>50$ & $>50$ & $>50$ & $>50$ & $>50$ \\
\hline
\end{tabular}

${ }^{a} \mathrm{IC}_{50}$ values are presented as the mean $\pm \mathrm{SD}$ (standard error of the mean) from three separated experiments.

the number of apoptotic cells was estimated by flow cytometry (Fig. 4). Four quadrant images were observed by flow cytometric analysis: the Q1 area represented damaged cells that appeared during the process of cell collection; the Q2 region showed necrotic cells and later stage apoptotic cells; early apoptotic cells were located in the Q3 area, and the Q4 area showed normal cells. A dose-dependent increase in the percentage of apoptotic cells was noted after the cells were treated with compound I-11 at the concentrations of $5 \mu \mathrm{M}, 10 \mu \mathrm{M}$ and $15 \mu \mathrm{M}$ for 24 h. As shown in Fig. 4 and 5, few (4.79\%) apoptotic cells were present in the control panel; in contrast, the percentage rose to $19.35 \%$ at the concentration of $5 \mu \mathrm{M}$ after treatment with I-11 for $24 \mathrm{~h}$. At concentrations of $10 \mu \mathrm{M}$ and $15 \mu \mathrm{M}$, there was a further increase to $42.3 \%$ and $43.4 \%$ after treatment with I-11, respectively. These results clearly confirm that compared with the control, compound I-11 effectively induced apoptosis in NCI-H460 cells in a dose-dependent manner.

2.2.4 Morphological characterization of NCI-H460 cell apoptosis by Hoechst 33258. In order to further validate cell apoptosis following treatment with compound I-11, NCI-H460 


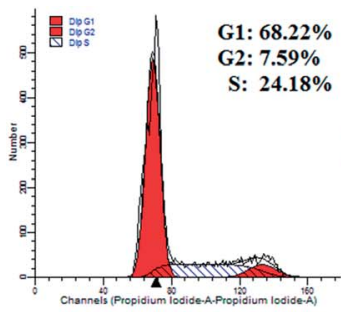

(a)

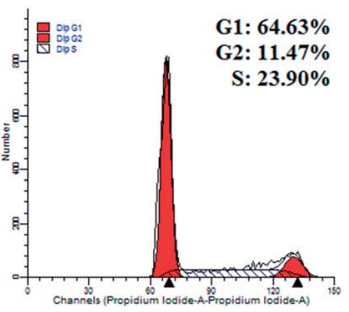

(b)

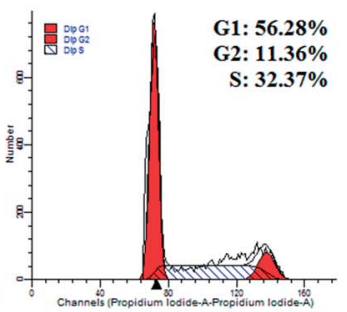

(c)

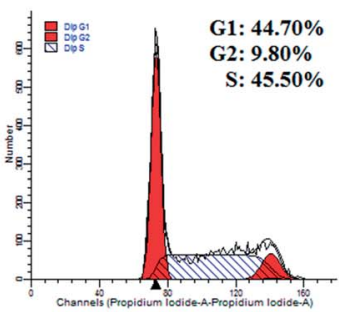

(d)

Fig. 2 Investigation of cell cycle distribution of compound I-11 by flow cytometric analysis. (a) Untreated $\mathrm{NCl}-\mathrm{H} 460 \mathrm{cells}$ as a control. (b, c, and d) Cells were treated with increasing concentrations of compound I-11 $(2 \mu \mathrm{M}, 4 \mu \mathrm{M}$ and $8 \mu \mathrm{M})$ for $48 \mathrm{~h}$, respectively.

cells treated with compound $\mathbf{I}-11$ at $10 \mu \mathrm{M}$ from 6 to $24 \mathrm{~h}$ were stained with Hoechst 33258. Control cells exhibited weak blue fluorescence (Fig. 6a); following treatment with compound I-11, some cells emitted brilliant blue fluorescence, and the nuclei of NCI-H460 cells appeared hyper-condensed (brightly stained). The number of apoptotic nuclei containing condensed chromatin increased significantly when NCI-H460 cells were treated with compound I-11 for $24 \mathrm{~h}$, indicating that apoptosis of NCIH460 cells was induced by compound I-11 in a time-dependent manner.

2.2.5 Compound I-11 induces release of intracellular calcium. Conditions such as drug treatment, which interfere with ER function and induced endoplasmic reticulum (ER) stress and swelling, causing cavities or the accumulation of unfolded proteins in the ER or misfolded proteins, play a crucial role in the ER stress-related protein degradation pathway. ${ }^{38}$ The ER is the primary storage site for intracellular calcium, and pumps in the ER membrane maintain a calcium gradient $\sim 1000$-fold higher than that in the cytoplasm. ${ }^{39}$ To determine whether I-11 induced the release of intracellular calcium in NCIH460 cells, the calcium level was measured with and without (control) I-11 $(10 \mu \mathrm{M})$ treatment for 6 to $24 \mathrm{~h}$, using the fluorescent probe fluo-3-acetoxymethyl-ester (Fluo-3/AM) and flow cytometry. In the control cells, the level of intracellular calcium was lowest (Fig. 7). Treatment of NCI-H460 cells with compound

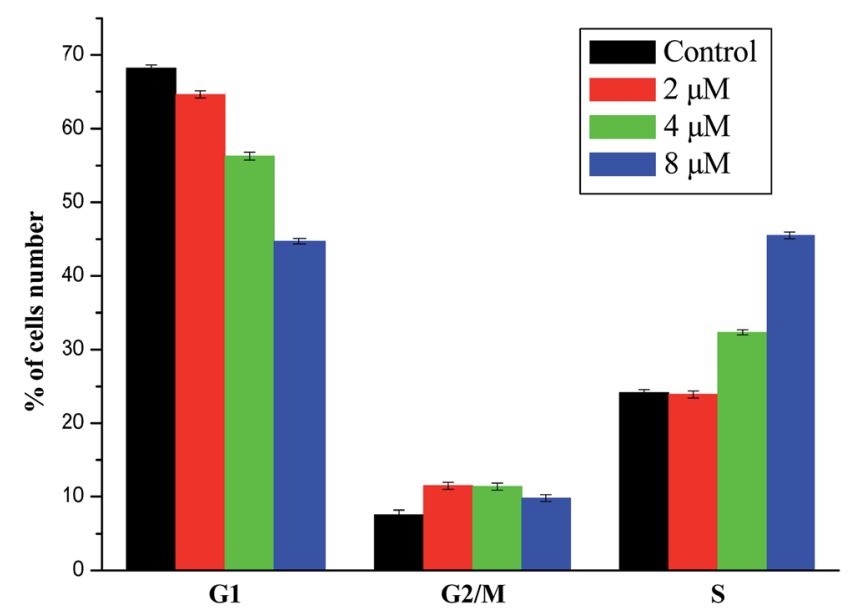

Fig. 3 The percentages of $\mathrm{NCl}-\mathrm{H} 460$ cells in different phases of cell cycle are presented.
I-11 increased the level of intracellular calcium within $6 \mathrm{~h}$ of treatment, and the highest level of intracellular calcium was observed after treatment for $24 \mathrm{~h}$. Therefore, these findings indicate that compound $\mathbf{I}-\mathbf{1 1}$ can significantly increase the intracellular level of calcium released.

2.2.6 Compound I-11 disrupts mitochondrial membrane potential. Cytoplasmic calcium is rapidly taken up by the mitochondria resulting in mitochondrial swelling and loss of mitochondrial membrane potential (MMP). ${ }^{39}$ The loss of MMP is regarded as a limiting factor in the apoptotic pathway. In order to further investigate the antiproliferative effect of target compound I-11, changes in MMP were detected using the fluorescent probe JC-1, which exhibits potential dependent accumulation in mitochondria, indicated by a fluorescence emission shift from red $(\sim 590 \mathrm{~nm})$ to green $(\sim 545 \mathrm{~nm})$. In the control cells, JC-1 aggregated in the mitochondria and showed strong red fluorescence. However, in cells undergoing apoptosis, where the mitochondrial potential had collapsed, JC-1 was located in the cytosol as a monomer and emitted green fluorescence. NCI-H460 cells treated with compound I-11 at 10 $\mu \mathrm{M}$ from 6 to $24 \mathrm{~h}$ were stained with JC- 1 for $24 \mathrm{~h}$ and cells not treated with compound $\mathbf{I}-\mathbf{1 1}$ were used as controls.

The results are shown in Fig. 8. The JC-1 monomer and J-aggregates were excited at $514 \mathrm{~nm}$ and $585 \mathrm{~nm}$, respectively, and light emissions were collected at $515-545 \mathrm{~nm}$ (green) and $570-600 \mathrm{~nm}$ (red). Fluorescence microscopy (Fig. 8) showed that cells not treated with compound I-11 were normally red (in the web version), while cells treated with I-11 showed strong yellowgreen fluorescence and typical apoptotic morphology after $6 \mathrm{~h}$, $12 \mathrm{~h}$ and $24 \mathrm{~h}$, suggesting the occurrence of mitochondrial depolarization by I-11.

2.2.7 Compound I-11 triggers ROS generation. Reactive oxygen species (ROS) are highly harmful to cells as they initiate oxidative stress and ultimately cause cellular damage. Excessive ROS generation renders cells vulnerable to apoptosis. ${ }^{40}$ To determine whether I-11 triggers ROS generation in NCI-H460 cells to induce apoptosis, the ROS level was measured with and without (control) I-11 $(10 \mu \mathrm{M})$ treatment for 6 to $24 \mathrm{~h}$, using the fluorescent probe 2,7-dichlorofluorescein diacetate (DCFDA) and flow cytometry. As shown in Fig. 9, compound I-11 induced an increase in ROS levels in NCI-H460 cells. After exposure to $10 \mu \mathrm{M}$ of compound I-11 for $24 \mathrm{~h}$, the ROS level was $42.6 \%$, which was more than three times that of the control. Taken together, these results show that $\mathbf{I}-\mathbf{1 1}$ caused oxidative 


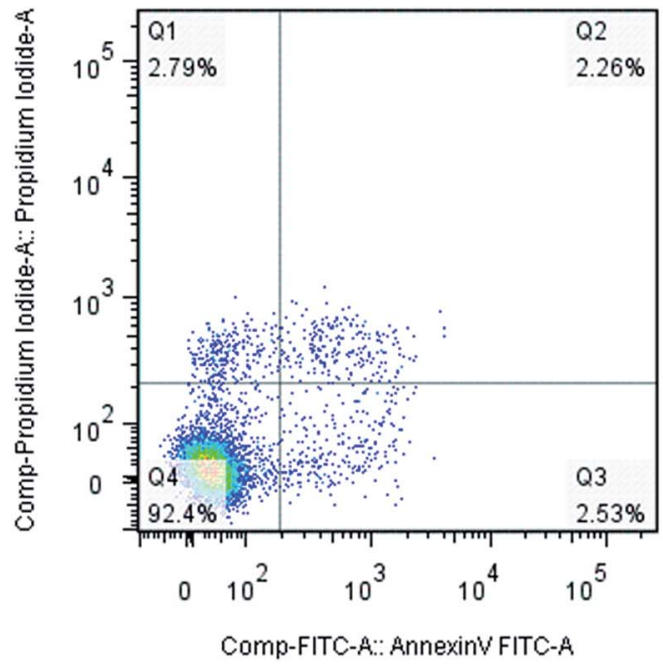

(a)

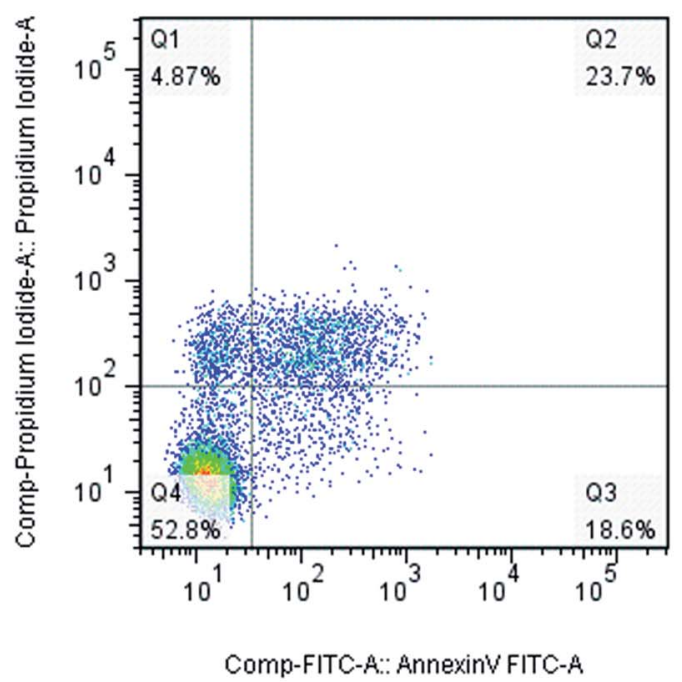

(c)

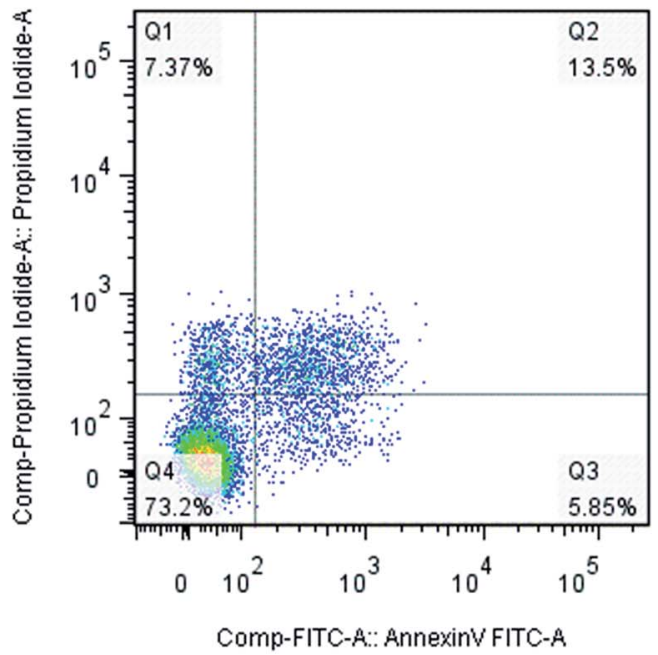

(b)

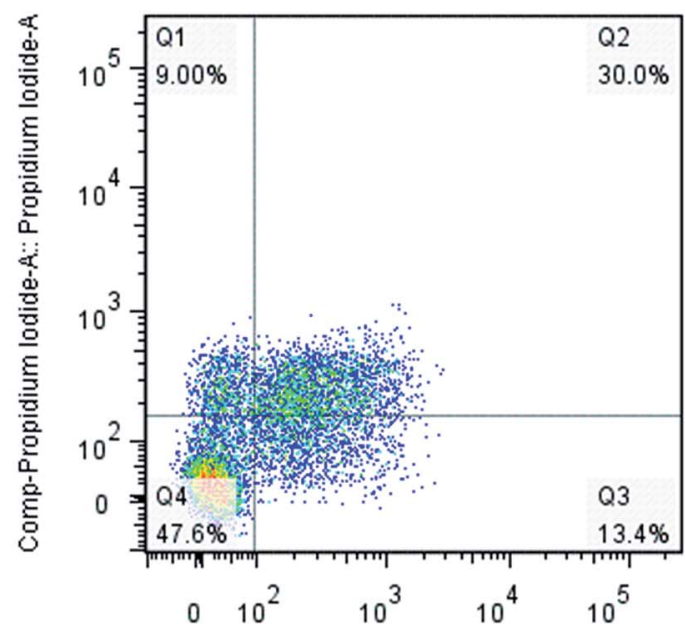

Comp-FITC-A:: AnnexinV FITC-A

(d)

Fig. 4 Apoptosis ratio detection of compound I-11 by Annexin V/PI assay. (a) NCl-H460 cells not treated with I-11. (b, c, and d) NCl-H460 cells treated with compound I-11 at $5 \mu \mathrm{M}, 10 \mu \mathrm{M}$ and $15 \mu \mathrm{M}$ for $24 \mathrm{~h}$, respectively.

imbalance in NCI-H460 cells. This induction of oxidative burst is a key factor in the antiproliferative activity of compound I-11.

2.2.8 Compound I-11 induces eIF2 $\alpha$ phosphorylation. In general, ER stress removes proteins accumulated in the ER and promotes cell survival by inhibiting protein synthesis, while overload or sustained ER stress induces cell death through a series of signaling pathways, including the CHOP pathway, IRE1 $\alpha$-ASK1-JNK pathway and Caspase-12 pathway. $^{38}$ The pancreatic ER kinase (PKR)-like ER kinase (PERK), a transmembrane protein kinase in the ER stress signaling network, was previously shown to phosphorylate eIF $2 \alpha$ in response to ER stress. The activation of PERK also leads to the induction of CHOP, which, as detailed later, is an important element in the switch from pro-survival to pro-death signaling. To further investigate the molecular mechanism of compound I-11 against NCI-H460 cells to gain further insight into its mode of action, we monitored the changes in apoptotic molecules related to the ER stress signaling pathway. A number of key protein markers involved in this signaling network were also examined by western blot analysis. As shown in Fig. 10a, treatment of NCIH460 cells with I-11 caused a significant increase in the levels of GRP78 and CHOP, in a dose-dependent manner. Furthermore, in comparison with the control cells, compound I-11 induced eIF2 $\alpha$ and PERK phosphorylation.

2.2.9 Activation of caspases. Intracellular calcium plays a central role in the regulation of calpain activity. ${ }^{\mathbf{4 1}}$ It is known that calcium-activated calpain can cleave cellular proteins, which results in cell swelling, membrane rupture, and cell death. Calpain and caspase are cysteine proteases and have important roles in the initiation, regulation and execution of cell death such as apoptosis and necrosis. ${ }^{42}$ As illustrated in Fig. 10b, calcium overload was observed in NCI-H460 cells 


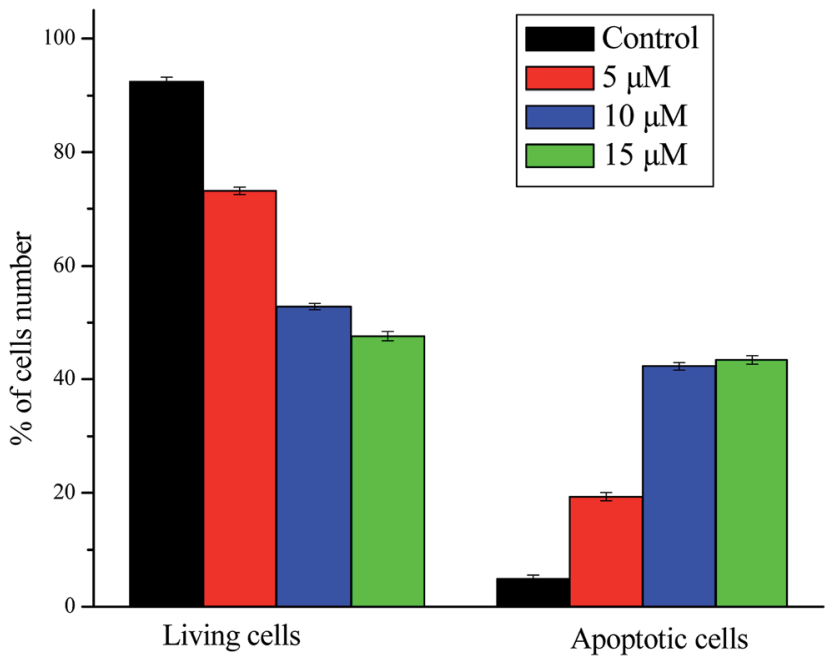

Fig. 5 Populations of apoptotic $\mathrm{NCl}-\mathrm{H} 460$ cells treated with increasing concentrations of compound I-11 $(5 \mu \mathrm{M}, 10 \mu \mathrm{M}$ and $15 \mu \mathrm{M})$ obtained by FACS analysis with PI and FITC-Annexin V staining.

following treatment with compound I-11; therefore, we hypothesized that elevated caspase-12/caspase- 4 and calpain activity may be triggered by calcium overload. As shown in Fig. 10b, target compound I-11 caused a significant timedependent induction of caspase- 12 and caspase- 4 expression. In addition, we also demonstrated that treatment with compound I-11 significantly activated the downstream death receptor cascade, as evidenced by increased caspase- 9 levels in the cytoplasm, which may further amplify mitochondrial membrane permeability.

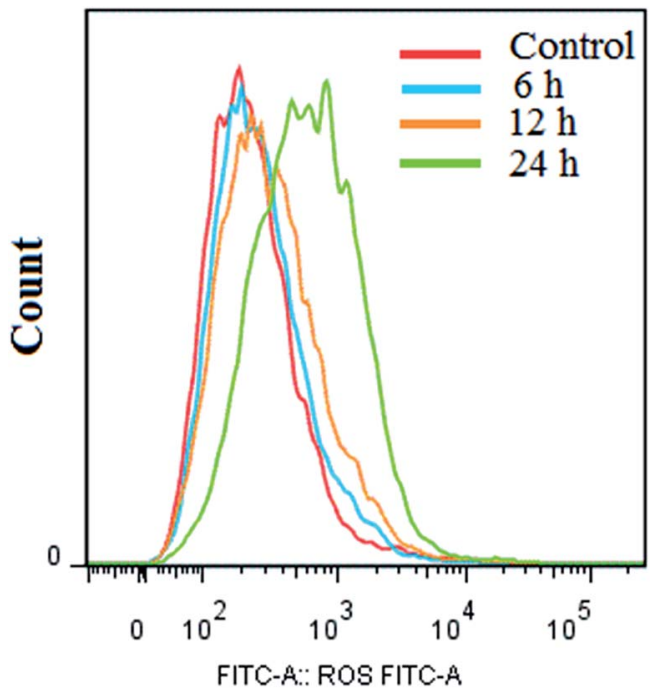

Fig. 7 Effects of compound I-11 on the intracellular free $\mathrm{Ca}^{2+}$ levels in $\mathrm{NCl}-\mathrm{H} 460$ cells. After treatment with compound I-11 $(10 \mu \mathrm{M})$ for $6 \mathrm{~h}$, $12 \mathrm{~h}$ and $24 \mathrm{~h}$, respectively, $\mathrm{NCl}-\mathrm{H} 460$ cells stained with Fluo-3AM for 30 min were analyzed by flow cytometry.

\section{Conclusion}

A series of dipeptide thiourea derivatives were designed and synthesized as potential antitumor agents with high selectivity. These compounds exhibited significant selectivity against different cancer cell lines with $\mathrm{IC}_{50}$ values at micromolar concentrations. It is noteworthy that further antitumor activity screening revealed that some compounds exhibited better

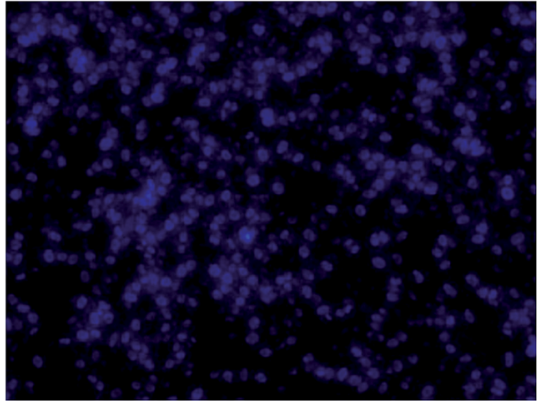

(a)

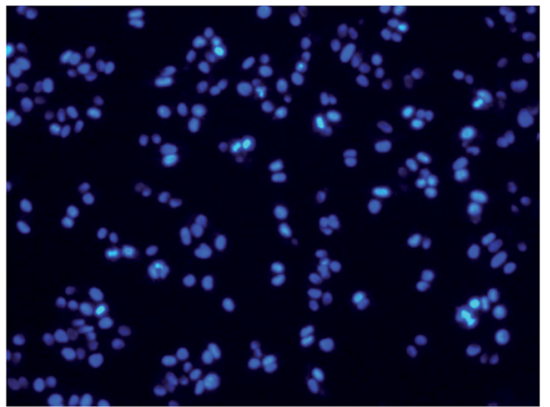

(c)

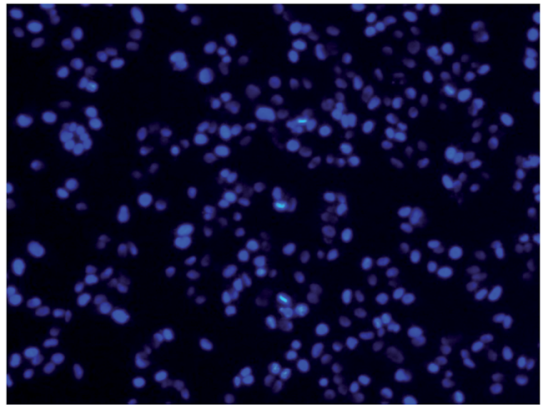

(b)

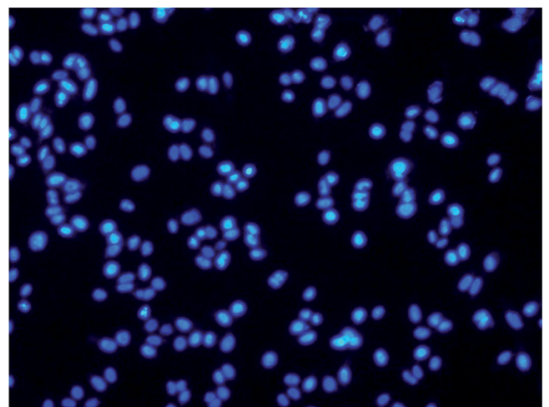

(d)

Fig. 6 Hoechst 33258 staining of compound I-11 in NCl-H460 cells. (a) Cells not treated with compound l-11 were used as control. (b, c, and d) Treatment with compound I-11 $(10 \mu \mathrm{M})$ for $6 \mathrm{~h}, 12 \mathrm{~h}$ and $24 \mathrm{~h}$, respectively. 


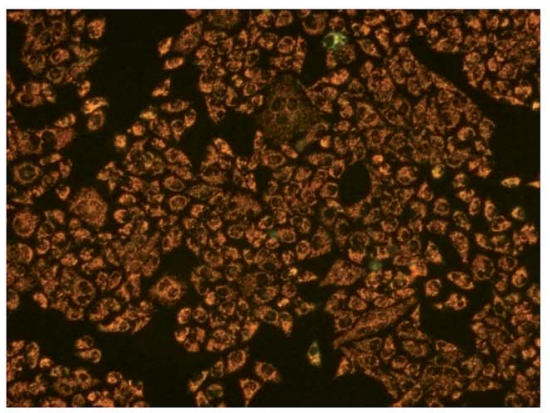

(a)

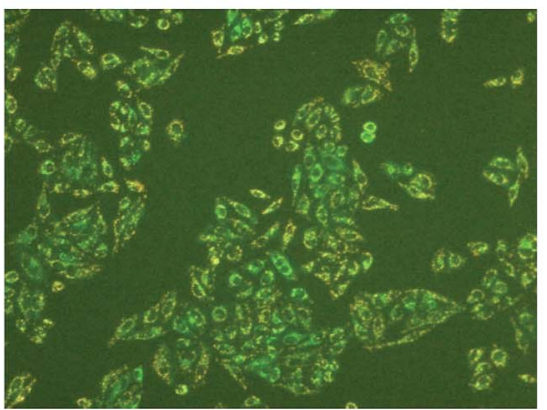

(c)

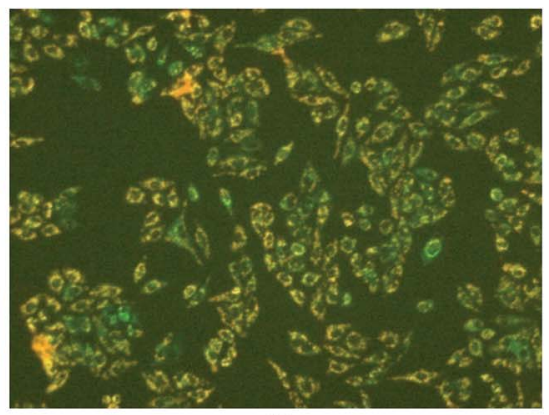

(b)

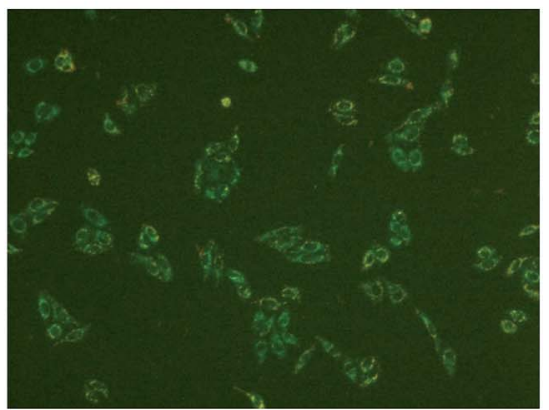

(d)

Fig. 8 JC-1 staining of compound I-11 in NCl-H460 cells. (a) Cells not treated with compound I-11 were used as control. (b, c, and d) Treatment with compound I-11 (10 $\mu \mathrm{M})$ for 6 h, $12 \mathrm{~h}$ and $24 \mathrm{~h}$, respectively.

inhibitory activity than the commercial anticancer drug 5 -Fu and Ube. In particular, compound $\mathrm{I}-11\left(\mathrm{IC}_{50}=4.85 \pm 1.44 \mu \mathrm{M}\right)$ exhibited the best anticancer activity against the NCI-H460 cell line and displayed more potent inhibitory activity than 5-Fu and Ube. The apoptosis-inducing activity of representative compound I-11 in NCI-H460 cells was investigated by Hoechst 33258 staining, JC-1 mitochondrial membrane potential staining, and flow cytometry. Simultaneous molecular mechanism studies suggested that target compound I-11 induced apoptosis in NCI-H460 cells through induction of ER stress-reactive oxygen species. Furthermore, cell cycle analysis indicated that compound I-11 arrested the NCI-H460 cell line in the S phase. The possible mechanism involved in compound I-11 induced apoptosis is shown in Fig. 11. Consequently, the rational design of dipeptide thiourea derivatives offers significant potential for the discovery of a new class of antitumor agents. The precise mechanism of this action requires further investigation.

\section{Experimental}

\subsection{General information}

The isothiocyanate was synthesized according to the literature. ${ }^{34}$ Compound $\mathbf{H}$ was synthesized according to the literature. ${ }^{43}$ All the chemical reagents and solvents used were of analytical grade. Aniline derivatives and all N-Boc protection amino acids during the synthesis were commercially available and purchased from Aladdin and Energy Chemical. Silica gel (300-400 mesh) used in column chromatography was provided by Tsingtao Marine Chemistry Co. Ltd. Precoated silica gel plates F-254 were used for thin-layer analytical chromatography.
${ }^{1} \mathrm{H}-\mathrm{NMR}$ and ${ }^{13} \mathrm{C}$-NMR spectra were recorded on a Bruker AMX400 and AMX-500 spectrometer. High-resolution mass spectra (HRMS) were recorded using ESI and APCI ionization sources.

\subsection{Experimental section}

4.2.1 General procedure for isothiocyanate compounds. Toluene $(20 \mathrm{~mL})$ was added to the amine $(10 \mathrm{mmol})$ and $\mathrm{Et}_{3} \mathrm{~N}$ (30.3 mmol). $\mathrm{CS}_{2}(30.3 \mathrm{mmol}$ ) was added while stirring, resulting in the precipitation of the dithiocarbamate. The reaction mixture was stirred for $9 \mathrm{~h}$ at room temperature and then filtered and dried. The resulting powder was suspended in the $\mathrm{CH}_{2} \mathrm{Cl}_{2}(20 \mathrm{~mL})$, and cooled to $0{ }^{\circ} \mathrm{C}$ and then BTC $(3.3 \mathrm{mmol})$ was added. After completing the reaction at room temperature for $1 \mathrm{~h}$, refluxing was continued for $2 \mathrm{~h}$. Insolubles were removed by filtration, and the solvent was purified by chromatography on silica gel eluted with petroleum ether to offer isothiocyanate.

4.2.2 General procedure for compounds $\mathrm{C}$ and $\mathrm{F}$. To a stirred solution of $N$-t-butyloxycarbonyl-L-amino $(5.5 \mathrm{mmol})$ in DMF $(10 \mathrm{~mL})$, was added $\mathrm{Et}_{3} \mathrm{~N}(12.5 \mathrm{mmol})$ and HOBT $(7.5$ $\mathrm{mmol})$. The mixture was allowed to stir for $1 \mathrm{~h}$ and then cooled to $0{ }^{\circ} \mathrm{C}$ and then EDCI $(7.5 \mathrm{mmol})$ was added. After $1 \mathrm{~h}$, a solution of aniline derivatives $(5 \mathrm{mmol})$ in DMF $(10 \mathrm{~mL})$ was added to the above reaction mixture. The resulting mixture was stirred for $7 \mathrm{~h}$ at room temperature. After completion as monitored by TLC, the reaction was quenched with water and extracted with EtOAc. The organic layer was washed with saturated brine solution, followed by drying over $\mathrm{Na}_{2} \mathrm{SO}_{4}$ and evaporating in vacuo. The crude product was purified by column 


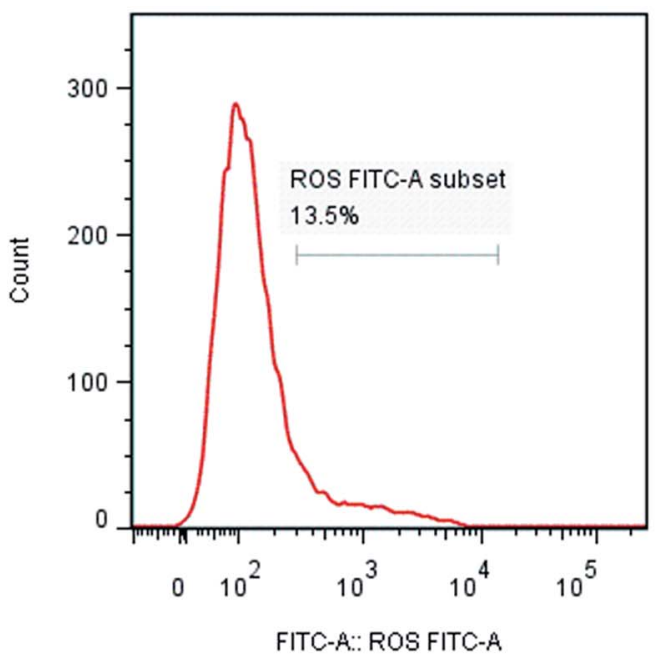

(a)

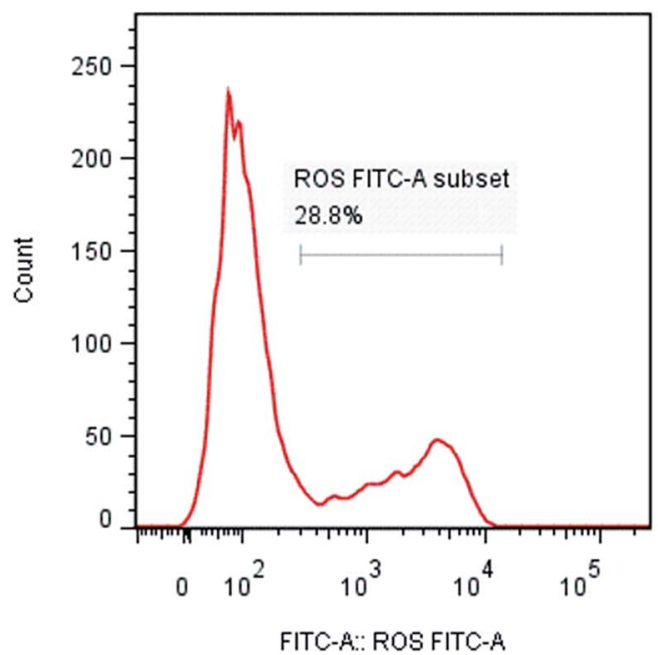

(c)

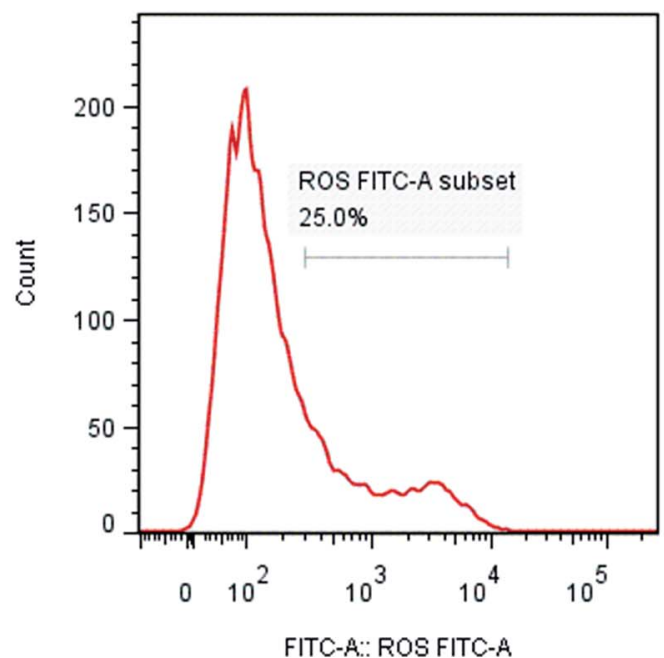

(b)

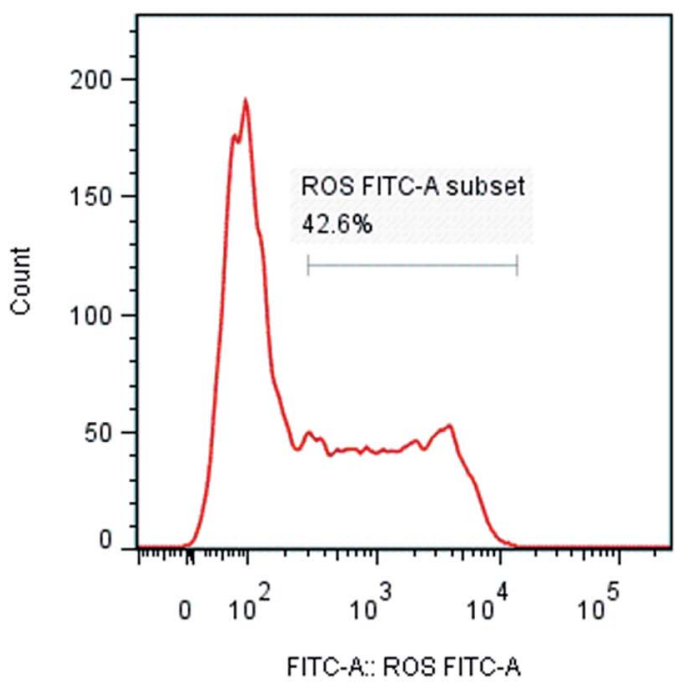

(d)

Fig. 9 ROS generation assay of compound I-11 in NCl-H460 cells. (a) Cells not treated with I-11 were used as the control for $24 \mathrm{~h}$. (b, $\mathrm{c}$, and d) Treatment with compound I-11 $(10 \mu \mathrm{M})$ for $6 \mathrm{~h}, 12 \mathrm{~h}$ and $24 \mathrm{~h}$, respectively.

chromatography (EtOAc/petroleum ether) to give the pure intermediates $\mathbf{C}$ and $\mathbf{F}$.

4.2.3 General procedure for compounds $\mathrm{D}$ and $\mathrm{H}$. To a round flask was added $\mathbf{C}$ or $\mathbf{F}$ and a standard $50 \% \mathrm{TFA} / \mathrm{CH}_{2} \mathrm{Cl}_{2}$. The sample was stirred at room temperature for $3 \mathrm{~h}$. The solvent was removed under reduced pressure and the residue was partitioned between $\mathrm{NaHCO}_{3}$ and EtOAc. The solvent of the organic layer was removed under reduced pressure. The residue thus obtained was purified by column chromatography (EtOAc/ petroleum ether) to give the deprotection of the Boc group to unmask the free amine $\mathbf{D}$ and $\mathbf{H}$.

4.2.4 General procedure for compounds I. Compounds I were obtained by the condensation of isothiocyanates with $\mathbf{F}$ in $\mathrm{CH}_{2} \mathrm{Cl}_{2}$ at room temperature. The structures were confirmed by ${ }^{1} \mathrm{H}$ NMR, ${ }^{13} \mathrm{C}$ NMR and HR-MS (see ESI $\dagger$ ). The spectral data for the representative compounds are shown in detail.
1-(1-(1-(2,5-Dimethoxyphenylamino)-1-oxo-3-phenylpropan-2ylamino)-3-methyl-1-oxopentan-2-yl)-3-(3-nitrophenyl)thiourea (I1). Yield $77.4 \%$. Mp $187.5-190.1^{\circ} \mathrm{C}$. $[\alpha]_{\mathrm{D}}^{20}=-29.2$ (c 0.1, AcOEt). ${ }^{1} \mathrm{H}$ NMR (400 MHz, DMSO- $\left.d_{6}\right) \delta 10.15(\mathrm{~s}, 1 \mathrm{H}), 9.06(\mathrm{~s}, 1 \mathrm{H}), 8.84$ $(\mathrm{s}, 1 \mathrm{H}), 8.61(\mathrm{~d}, J=7.9 \mathrm{~Hz}, 1 \mathrm{H}), 7.97(\mathrm{~d}, J=8.5 \mathrm{~Hz}, 1 \mathrm{H}), 7.92(\mathrm{dd}$, $J=8.2,1.5 \mathrm{~Hz}, 1 \mathrm{H}), 7.83(\mathrm{dd}, J=8.1,1.2 \mathrm{~Hz}, 1 \mathrm{H}), 7.73(\mathrm{~d}, J=$ $2.7 \mathrm{~Hz}, 1 \mathrm{H}), 7.58(\mathrm{t}, J=8.2 \mathrm{~Hz}, 1 \mathrm{H}), 7.33(\mathrm{~d}, J=7.3 \mathrm{~Hz}, 2 \mathrm{H}), 7.23$ $(\mathrm{t}, J=7.4 \mathrm{~Hz}, 2 \mathrm{H}), 7.16(\mathrm{~d}, J=7.3 \mathrm{~Hz}, 1 \mathrm{H}), 6.94(\mathrm{~d}, J=9.0 \mathrm{~Hz}$, $1 \mathrm{H}), 6.62(\mathrm{dd}, J=8.9,3.0 \mathrm{~Hz}, 1 \mathrm{H}), 5.00-4.90(\mathrm{~m}, 1 \mathrm{H}), 4.82$ (dd, $J$ $=13.0,8.7 \mathrm{~Hz}, 1 \mathrm{H}), 3.76(\mathrm{~s}, 3 \mathrm{H}), 3.68(\mathrm{~s} 3 \mathrm{H}), 3.15$ and $2.96(\mathrm{dd}, J$ $=13.9,4.7 \mathrm{~Hz}, 1 \mathrm{H}$; dd $J=13.8,9.7 \mathrm{~Hz}, 1 \mathrm{H}), 1.90-1.80(\mathrm{~m}, 1 \mathrm{H})$, 1.44 and 1.08 (ddd, $J=13.1,7.4,3.1 \mathrm{~Hz}, 1 \mathrm{H}$; td, $J=13.7,8.2 \mathrm{~Hz}$, $1 \mathrm{H}), 0.91-0.73\left(\mathrm{~m}, 6 \mathrm{H}, 2 \times \mathrm{CH}_{3}\right) .{ }^{13} \mathrm{C}$ NMR (100 MHz, DMSO- $\left.d_{6}\right)$ $\delta 180.4,170.9,169.7,152.9,147.5,143.1,141.0,137.6,129.7$, $129.3,129.3,128.0,128.0,127.8,126.2,117.9,115.9,111.8$, 108.0, 107.5, 60.9, 56.2, 55.3, 55.3, 54.9, 37.5, 36.7, 24.3, 15.1, 

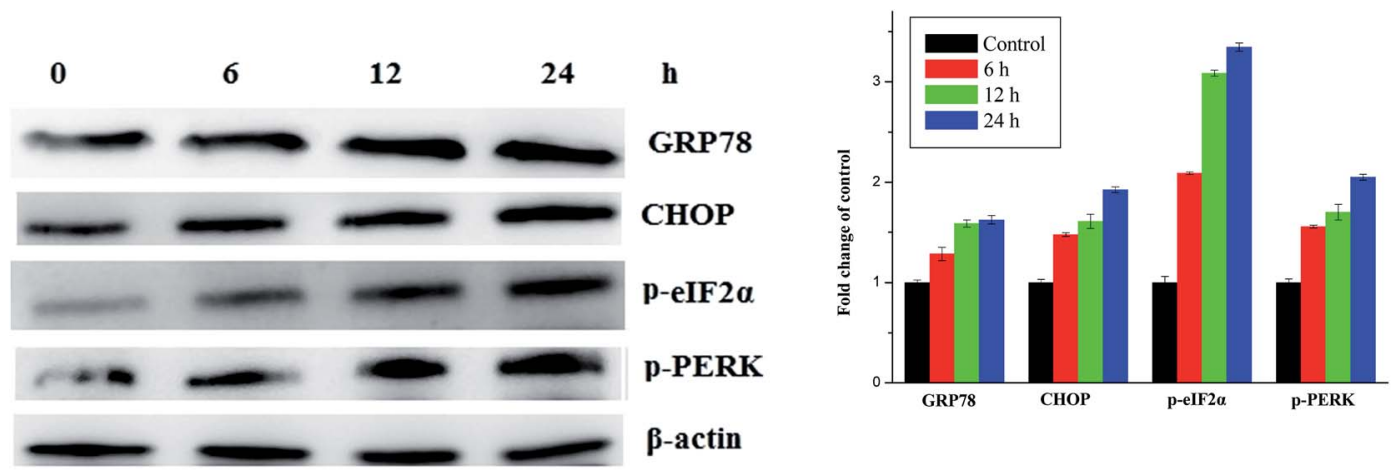

$\boldsymbol{\beta}$-actin

(a)
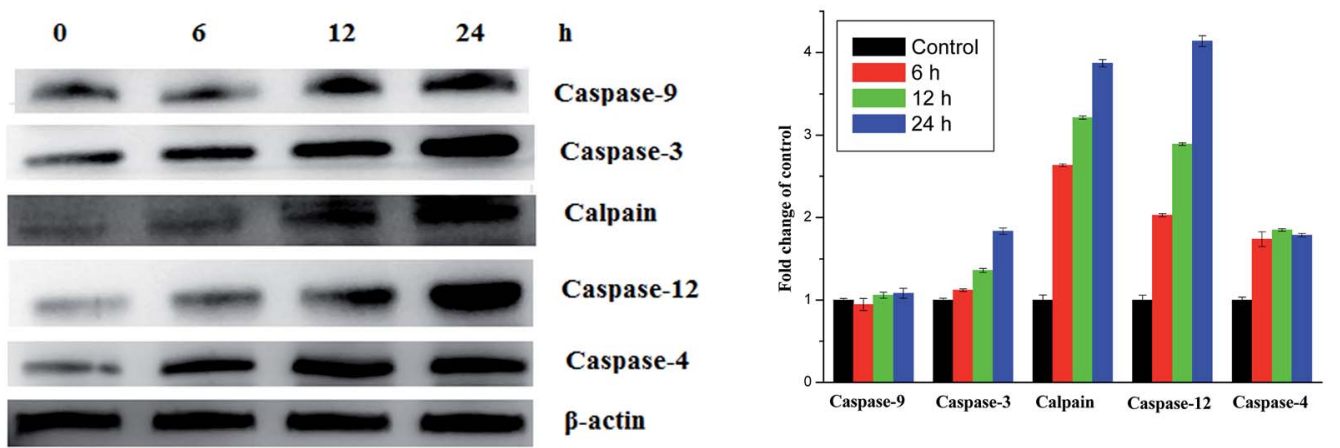

(b)

Fig. 10 Western blotting analysis effect of compound I-11 on the expression of (b) caspase-9, caspase-3, caspase-12, calpain, caspase-4, (a) CHOP, GRP78, p-PERK and p-elF2 $\alpha$ in NCl-H460 cells. NCl-H460 cells were treated with compound I-11 at $10 \mu \mathrm{M}$ for $6 \mathrm{~h}, 12 \mathrm{~h}$ and $24 \mathrm{~h}$, respectively. Equal amounts of protein were loaded on SDS-PAGE gel for western blot analysis as described in the experimental section. $\beta$-Actin was used as an internal control.

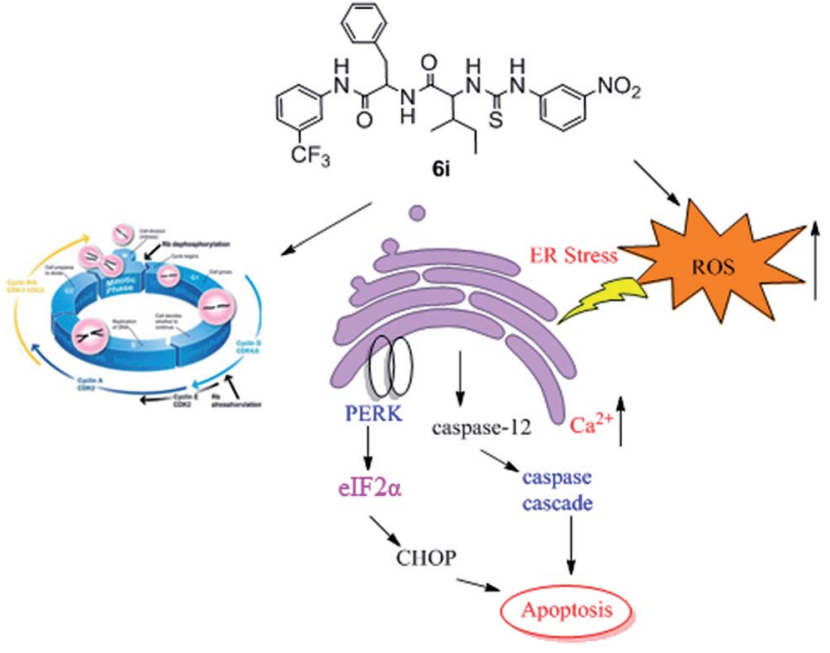

Fig. 11 The signaling pathways for apoptosis and cell cycle arrest induced by compound I-11.

11.3. ESI-HRMS $m / z$ calcd for $\mathrm{C}_{30} \mathrm{H}_{35} \mathrm{~N}_{5} \mathrm{O}_{6} \mathrm{~S}[\mathrm{M}+\mathrm{H}]^{+}: 594.2381$; found: 594.2355 .

1-(3-Chlorophenyl)-3-(1-(1-(4-methoxyphenylamino)-1-oxo-3phenylpropan-2-ylamino)-3-methyl-1-oxopentan-2-yl)thiourea (I5). Yield 76.5\%. Mp $169.9-173.5^{\circ} \mathrm{C}$. $[\alpha]_{\mathrm{D}}^{20}=-27.0$ (c 0.1, AcOEt).
${ }^{1} \mathrm{H}$ NMR (400 MHz, DMSO- $\left.d_{6}\right) \delta 9.92(\mathrm{~s}, 1 \mathrm{H}), 9.74(\mathrm{~s}, 1 \mathrm{H}), 8.35$ (d, $J=8.0 \mathrm{~Hz}, 1 \mathrm{H}), 7.96(\mathrm{~s}, 1 \mathrm{H}), 7.83(\mathrm{~d}, J=8.1 \mathrm{~Hz}, 1 \mathrm{H}), 7.46(\mathrm{~d}, J=$ $8.9 \mathrm{~Hz}, 2 \mathrm{H}), 7.35$ (dd, $J=10.3,8.1 \mathrm{~Hz}, 2 \mathrm{H}), 7.29(\mathrm{~d}, J=7.0 \mathrm{~Hz}$, $2 \mathrm{H}), 7.24(\mathrm{t}, J=7.4 \mathrm{~Hz}, 2 \mathrm{H}), 7.17(\mathrm{~d}, J=7.1 \mathrm{~Hz}, 1 \mathrm{H}), 7.13(\mathrm{~d}, J=$ $7.4 \mathrm{~Hz}, 1 \mathrm{H}), 6.87$ (d, $J=9.0 \mathrm{~Hz}, 2 \mathrm{H}), 4.85$ (d, $J=6.5 \mathrm{~Hz}, 1 \mathrm{H}), 4.70$ (dd, $J=13.9,8.4 \mathrm{~Hz}, 1 \mathrm{H}), 3.72(\mathrm{~s}, 3 \mathrm{H}), 3.09$ and $2.95(\mathrm{dd}, J=$ 13.8, $5.2 \mathrm{~Hz}, 1 \mathrm{H}$; dd, $J=13.7,9.3 \mathrm{~Hz}, 1 \mathrm{H}), 1.83(\mathrm{~d}, J=6.1 \mathrm{~Hz}$, $1 \mathrm{H}), 1.39$ and $1.11-0.97$ (dd, $J=11.9,5.6 \mathrm{~Hz}, 1 \mathrm{H} ; \mathrm{m}, 1 \mathrm{H}), 0.82$ (d, $\left.J=7.8 \mathrm{~Hz}, 6 \mathrm{H}, 2 \times \mathrm{CH}_{3}\right) .{ }^{13} \mathrm{C}$ NMR $\left(100 \mathrm{MHz}, \mathrm{DMSO}-d_{6}\right) \delta 180.3$, 170.5 , 169.1, 155.4, 141.2, 137.6, 132.5, 131.8, 130.0, 129.2, 129.2 , 128.0, 128.0, 126.3, 123.4, 121.4, 121.4, 121.0, 120.4, 113.8, 113.8, 61.2, 55.1, 54.7, 37.5, 37.4, 24.4, 15.2, 11.4. ESIHRMS $m / z$ calcd for $\mathrm{C}_{29} \mathrm{H}_{33} \mathrm{ClN}_{4} \mathrm{O}_{3} \mathrm{~S}[\mathrm{M}-\mathrm{H}]^{-}$: 551.1889; found: 551.1903 .

$\mathrm{N}$-(1-Oxo-3-phenyl-1-((3-(trifluoromethyl)phenyl)amino)propan2-yl)-3-phenyl-2-(3-(3-(trifluoromethyl)phenyl)thioureido) propanamide $(\mathbf{I}-11)$. Yield 78.3\%. Mp 143.8-150.6 ${ }^{\circ} \mathrm{C} .[\alpha]_{\mathrm{D}}^{20}=$ -26.0 (c 0.1, AcOEt). ${ }^{1} \mathrm{H}$ NMR (500 MHz, DMSO- $\left.d_{6}\right) \delta 10.45$ (s, $1 \mathrm{H}), 10.15(\mathrm{~s}, 1 \mathrm{H}), 8.80(\mathrm{~d}, J=7.8 \mathrm{~Hz}, 1 \mathrm{H}), 8.10$ (s, 2H), 7.85 (d, $J$ $=7.5 \mathrm{~Hz}, 1 \mathrm{H}), 7.80(\mathrm{~d}, J=8.4 \mathrm{~Hz}, 1 \mathrm{H}), 7.59(\mathrm{dd}, J=17.8,9.0 \mathrm{~Hz}$, $2 \mathrm{H}), 7.50(\mathrm{t}, J=7.9 \mathrm{~Hz}, 1 \mathrm{H}), 7.42(\mathrm{dd}, J=15.7,7.8 \mathrm{~Hz}, 2 \mathrm{H}), 7.33$ $(\mathrm{d}, J=7.3 \mathrm{~Hz}, 2 \mathrm{H}), 7.28(\mathrm{t}, J=7.5 \mathrm{~Hz}, 2 \mathrm{H}), 7.22-7.16(\mathrm{~m}, 3 \mathrm{H})$, 7.15-7.10 (m, 3H), $5.18(\mathrm{dd}, J=12.3,6.8 \mathrm{~Hz}, 1 \mathrm{H}), 4.74(\mathrm{td}, J=$ 8.4, $5.9 \mathrm{~Hz}, 1 \mathrm{H}), 3.27$ (dd, $J=13.8,4.7 \mathrm{~Hz}, 1 \mathrm{H}), 3.13$ (dd, $J=13.9$, $5.6 \mathrm{~Hz}, 1 \mathrm{H}), 3.00$ (ddd, $J=13.7,7.7,5.9 \mathrm{~Hz}, 2 \mathrm{H}) .{ }^{13} \mathrm{C}$ NMR (125 
MHz, DMSO- $\left.d_{6}\right) \delta 179.8,170.5,170.4,140.3,139.5,137.3,136.9$, $130.1,129.7,129.6,129.4,129.0$, 128.2, 127.9, 126.5, 126.3, 125.9, 125.2, 125.1, 123.1, 123.00, 122.9, 120.2, 119.9, 118.4, 115.5, 115.4, 57.5, 55.0, 37.5. ESI-HRMS $\mathrm{m} / \mathrm{z}$ calcd for $\mathrm{C}_{33} \mathrm{H}_{28} \mathrm{~F}_{6} \mathrm{~N}_{4} \mathrm{O}_{2} \mathrm{~S}[\mathrm{M}+\mathrm{Na}]^{+}$: 681.1729; found: 681.1722 .

2-(3-(3-Chlorophenyl)thioureido)-N-(1-((3,5-dimethylphenyl) amino)-1-oxo-3-phenylpropan-2-yl)-3-phenylpropanamide (I-16). Yield 83.1\%. Mp 139.6-147.2 ${ }^{\circ} \mathrm{C}$. $[\alpha]_{\mathrm{D}}^{20}=-37.0$ (c 0.1, AcOEt). ${ }^{1} \mathrm{H}$ NMR $\left(500 \mathrm{MHz}, \mathrm{CDCl}_{3}\right) \delta 9.16(\mathrm{~d}, J=33.1 \mathrm{~Hz}, 2 \mathrm{H}), 8.69(\mathrm{~s}, 1 \mathrm{H})$, $7.63(\mathrm{~s}, 1 \mathrm{H}), 7.43(\mathrm{~s}, 1 \mathrm{H}), 7.24(\mathrm{~d}, J=6.0 \mathrm{~Hz}, 2 \mathrm{H}), 7.15(\mathrm{~s}, 3 \mathrm{H})$, $7.07(\mathrm{~s}, 2 \mathrm{H}), 6.96(\mathrm{~s}, 3 \mathrm{H}), 6.85(\mathrm{~s}, 1 \mathrm{H}), 6.78(\mathrm{~d}, J=6.8 \mathrm{~Hz}, 5 \mathrm{H})$, $5.44(\mathrm{~s}, 1 \mathrm{H}), 5.12(\mathrm{~s}, 1 \mathrm{H}), 3.19-2.96(\mathrm{~m}, 2 \mathrm{H}), 2.90(\mathrm{~d}, J=23.0 \mathrm{~Hz}$, 1H), $2.76(\mathrm{~s}, 1 \mathrm{H}), 2.07\left(\mathrm{~s}, 6 \mathrm{H}, 2 \times \mathrm{CH}_{3}\right) .{ }^{13} \mathrm{C} \mathrm{NMR}(125 \mathrm{MHz}$, $\left.\mathrm{CDCl}_{3}\right) \delta 179.8,171.0,170.7,139.7,140.0,139.0,136.4,136.2$, $135.4,134.3,129.9,129.6,128.7,128.3,127.6$, 127.2, 126.6, 125.6, 124.6, 122.9, 119.4, 59.1, 56.1, 39.24, 38.1, 21.2. ESIHRMS $m / z$ calcd for $\mathrm{C}_{33} \mathrm{H}_{33} \mathrm{ClN}_{4} \mathrm{O}_{2} \mathrm{~S}[\mathrm{M}+\mathrm{Na}]^{+}: 607.1905$; found: 607.1900 .

$\mathrm{N}$-(4-Bromophenyl)-2-(2-(3-(3-bromophenyl)thioureido)-3methylbutanamido)-3-methylpentanamide (I-20). Yield 88.2\%. Mp 126.7-131.1 ${ }^{\circ} \mathrm{C} .[\alpha]_{\mathrm{D}}^{20}=-26.9$ (c 0.1, AcOEt). ${ }^{1} \mathrm{H}$ NMR $(400 \mathrm{MHz}$, DMSO- $\left.d_{6}\right) \delta 10.21(\mathrm{~s}, 1 \mathrm{H}), 9.88(\mathrm{~s}, 1 \mathrm{H}), 8.25(\mathrm{~d}, J=7.9 \mathrm{~Hz}, 1 \mathrm{H})$, $7.84(\mathrm{~d}, J=8.0 \mathrm{~Hz}, 1 \mathrm{H}), 7.62-7.29(\mathrm{~m}, 8 \mathrm{H}), 4.94(\mathrm{~s}, 1 \mathrm{H}), 4.28(\mathrm{t}, J$ $=8.0 \mathrm{~Hz}, 1 \mathrm{H}), 2.12(\mathrm{dd}, J=12.7,6.4 \mathrm{~Hz}, 1 \mathrm{H}), 1.81(\mathrm{~d}, J=5.4 \mathrm{~Hz}$, $1 \mathrm{H}), 1.54$ (s, 1H), 1.24-1.06 (m, 1H), 0.85 (dd, $J=16.8,6.6 \mathrm{~Hz}$, $\left.12 \mathrm{H}, 4 \times \mathrm{CH}_{3}\right) .{ }^{13} \mathrm{C}$ NMR $\left(100 \mathrm{MHz}, \mathrm{DMSO}-d_{6}\right) \delta 180.4,170.7$, $170.3,139.1,138.2,131.6,131.5,131.2,131.1,124.2,121.2$, 115.6, 114.9, 61.2, 58.1, 36.2, 31.2, 24.6, 18.9, 18.2, 15.3, 10.9. ESI-HRMS $\mathrm{m} / \mathrm{z}$ calcd for $\mathrm{C}_{24} \mathrm{H}_{30} \mathrm{Br}_{2} \mathrm{~N}_{4} \mathrm{O}_{2} \mathrm{~S}[\mathrm{M}+\mathrm{K}]^{+}:$635.0088; found: 635.0080 .

N-(3-Chloro-4-fluorophenyl)-2-(2-(3-(3,4-dichlorophenyl) thioureido)-3-methylbutanamido)-3-methylpentanamide (I-25). Yield 80.5\%. Mp 129.5-133.2 ${ }^{\circ} \mathrm{C}$. $[\alpha]_{\mathrm{D}}^{20}=-21.8$ (c 0.1, AcOEt). ${ }^{1} \mathrm{H}$ NMR $\left(400 \mathrm{MHz}\right.$, DMSO- $\left.d_{6}\right) \delta 10.31(\mathrm{~s}, 1 \mathrm{H}), 10.01(\mathrm{~s}, 1 \mathrm{H}), 8.28(\mathrm{~d}, J$ $=8.0 \mathrm{~Hz}, 1 \mathrm{H}), 8.16(\mathrm{~s}, 1 \mathrm{H}), 7.98(\mathrm{~d}, J=8.2 \mathrm{~Hz}, 1 \mathrm{H}), 7.92(\mathrm{dd}, J=$ 6.8, $2.3 \mathrm{~Hz}, 1 \mathrm{H}), 7.53(\mathrm{~d}, J=8.7 \mathrm{~Hz}, 1 \mathrm{H}), 7.50-7.45(\mathrm{~m}, 1 \mathrm{H}), 7.43$ (dd, $J=8.8,2.3 \mathrm{~Hz}, 1 \mathrm{H}), 7.35(\mathrm{t}, J=9.1 \mathrm{~Hz}, 1 \mathrm{H}), 5.04-4.73(\mathrm{~m}$, $1 \mathrm{H}), 4.26(\mathrm{t}, J=8.1 \mathrm{~Hz}, 1 \mathrm{H}), 2.13(\mathrm{dd}, J=12.8,6.5 \mathrm{~Hz}, 1 \mathrm{H}), 1.82$ $(\mathrm{d}, J=6.2 \mathrm{~Hz}, 1 \mathrm{H}), 1.53(\mathrm{~d}, J=7.2 \mathrm{~Hz}, 1 \mathrm{H}), 1.20-1.12(\mathrm{~m}, 1 \mathrm{H})$, $0.87\left(\mathrm{dd}, J=15.8,8.4 \mathrm{~Hz}, 12 \mathrm{H}, 4 \times \mathrm{CH}_{3}\right) .{ }^{13} \mathrm{C} \mathrm{NMR}(100 \mathrm{MHz}$, DMSO- $\left.d_{6}\right) \delta 180.7,171.1,170.8,154.8,152.4,140.4,136.4,130.8$, 130.6, 125.5, 123.5, 122.4, 120.9, 117.5, 117.3, 61.7, 58.5, 36.6, 31.6, 25.0, 19.3, 18.6, 15.7, 11.2. ESI-HRMS $\mathrm{m} / \mathrm{z}$ calcd for $\mathrm{C}_{24^{-}}$ $\mathrm{H}_{28} \mathrm{Cl}_{3} \mathrm{FN}_{4} \mathrm{O}_{2} \mathrm{~S}[\mathrm{M}+\mathrm{Na}]^{+}$: 583.0875; found: 583.0870 .

$N$-(1-((3-Chlorophenyl)amino)-3-methyl-1-oxobutan-2-yl)-3methyl-2-(3-(3,4,5-trimethylphenyl)thioureido)pentanamide (I-30). Yield 83.6\%. Mp 148.6-152.3 ${ }^{\circ} \mathrm{C}$. $[\alpha]_{\mathrm{D}}^{20}=-11.7$ (c 0.1, AcOEt). ${ }^{1} \mathrm{H}$ NMR (400 MHz, $\left.\mathrm{CDCl}_{3}\right) \delta 8.72(\mathrm{~s}, 1 \mathrm{H}), 8.26(\mathrm{~s}, 1 \mathrm{H}), 7.59(\mathrm{t}, J=$ $1.8 \mathrm{~Hz}, 1 \mathrm{H}), 7.45(\mathrm{~s}, 1 \mathrm{H}), 7.34(\mathrm{~d}, J=8.2 \mathrm{~Hz}, 1 \mathrm{H}), 7.13(\mathrm{t}, J=$ $8.1 \mathrm{~Hz}, 1 \mathrm{H}), 7.07-6.98(\mathrm{~m}, 2 \mathrm{H}), 6.50(\mathrm{~s}, 2 \mathrm{H}), 5.01(\mathrm{t}, J=7.7 \mathrm{~Hz}$, $1 \mathrm{H}), 4.43(\mathrm{t}, J=8.0 \mathrm{~Hz}, 1 \mathrm{H}), 3.82\left(\mathrm{~s}, 3 \mathrm{H}, \mathrm{CH}_{3}\right), 3.74(\mathrm{~s}, 6 \mathrm{H}, 2 \times$ $\left.\mathrm{CH}_{3}\right), 2.31-2.11(\mathrm{~m}, 1 \mathrm{H}), 1.95-1.89(\mathrm{~m}, 1 \mathrm{H}), 1.60-1.51(\mathrm{~m}, 1 \mathrm{H})$, 1.17-1.06 (m, 1H), 0.99 (dd, $\left.J=6.7,2.9 \mathrm{~Hz}, 6 \mathrm{H}, 2 \times \mathrm{CH}_{3}\right), 0.91-$ $0.74\left(\mathrm{~m}, 6 \mathrm{H}, 2 \times \mathrm{CH}_{3}\right) .{ }^{13} \mathrm{C} \mathrm{NMR}\left(100 \mathrm{MHz}, \mathrm{CDCl}_{3}\right) \delta 180.7$, $172.1,170.1,153.9,153.2,138.6,134.7,130.1,124.8,120.3$, $118.3,103.6,102.5,63.1,61.0,60.2,56.3,56.2,37.6,30.5$,
25.6, 19.5, 18.6, 15.4, 12.8, 11.4. ESI-HRMS $\mathrm{m} / \mathrm{z}$ calcd for $\mathrm{C}_{27} \mathrm{H}_{37} \mathrm{ClN}_{4} \mathrm{O}_{2} \mathrm{~S}[\mathrm{M}+\mathrm{K}]^{+}$: 555.1957; found: 555.2003.

1-(1-(1-(3,4-Dimethylphenylamino)-3-methyl-1-oxobutan-2ylamino)-3-methyl-1-oxopentan-2-yl)-3-(3-nitrophenyl)thiourea (I36). Yield $80.4 \%$. Mp 194.5-195.4 ${ }^{\circ} \mathrm{C}$. $[\alpha]_{\mathrm{D}}^{20}=-22.7$ (c 0.1 , AcOEt). ${ }^{1} \mathrm{H}$ NMR (500 MHz, DMSO- $\left.d_{6}\right) \delta 10.17$ (s, 1H), $9.83(\mathrm{~d}, J=$ $20.0 \mathrm{~Hz}, 1 \mathrm{H}), 8.85(\mathrm{~s}, 1 \mathrm{H}), 8.14(\mathrm{~d}, J=8.5 \mathrm{~Hz}, 1 \mathrm{H}), 8.09$ (d, $J=$ $8.4 \mathrm{~Hz}, 1 \mathrm{H}), 7.90(\mathrm{dd}, J=8.2,1.5 \mathrm{~Hz}, 1 \mathrm{H}), 7.83(\mathrm{~d}, J=7.4 \mathrm{~Hz}$, $1 \mathrm{H}), 7.57(\mathrm{t}, J=8.2 \mathrm{~Hz}, 1 \mathrm{H}), 7.35(\mathrm{~s}, 1 \mathrm{H}), 7.29(\mathrm{dd}, J=8.1,1.9 \mathrm{~Hz}$, $1 \mathrm{H}), 7.03(\mathrm{~d}, J=8.2 \mathrm{~Hz}, 1 \mathrm{H}), 4.95(\mathrm{t}, J=7.4 \mathrm{~Hz}, 1 \mathrm{H}), 4.27(\mathrm{t}, J=$ $8.0 \mathrm{~Hz}, 1 \mathrm{H}), 2.15$ (d, $J=10.6 \mathrm{~Hz}, 6 \mathrm{H}), 2.04(\mathrm{dd}, J=14.2,7.1 \mathrm{~Hz}$, $1 \mathrm{H}), 1.92-1.87(\mathrm{~m}, 1 \mathrm{H}), 1.55-1.50$ and $1.16-1.10(\mathrm{~m}, 1 \mathrm{H} ; \mathrm{m}, 1 \mathrm{H})$, 0.95-0.87 (m, 9H, $\left.3 \times \mathrm{CH}_{3}\right), 0.85\left(\mathrm{t}, J=7.4 \mathrm{~Hz}, 3 \mathrm{H}, \mathrm{CH}_{3}\right) \cdot{ }^{13} \mathrm{C}$ NMR (125 MHz, DMSO- $\left.d_{6}\right) \delta 180.4,170.7,169.55,147.5,141.1$, $136.5,136.3,131.1,129.7,129.6,127.9,120.6$, 118.0, 116.9, 115.9, 61.0, 59.0, 37.4, 30.5, 24.6, 19.6, 19.2, 18.8, 18.6, 15.3, 11.3. ESI-HRMS $m / z$ calcd for $\mathrm{C}_{26} \mathrm{H}_{35} \mathrm{~N}_{5} \mathrm{O}_{4} \mathrm{~S}[\mathrm{M}-\mathrm{H}]^{-}:$: 512.2337; found: 512.2338 .

\subsection{Cytotoxicity assay}

The cell lines MGC-803, NCI-H460, Hct-116, HepG2, SKOV-3, and HUVEC were obtained from the Shanghai Cell Bank in the Chinese Academy of Sciences. MGC-803, NCI-H460, Hct116, HepG2, SKOV-3, and HUVEC cell lines were grown on 96well microtitre plates at a cell density of $10 \times 10^{5}$ cells per well in DMEM medium with 10\% FBS. DMEM and FBS were obtained from Gibco-Thermo (BRL Co. Ltd., USA). The plates were incubated at $37{ }^{\circ} \mathrm{C}$ in a humidified atmosphere of $5 \% \mathrm{CO}_{2} / 95 \%$ air overnight. The cells were exposed to different concentrations of compounds I and 5-Fu, and incubated for another $48 \mathrm{~h}$. The cells were stained with $10 \mu \mathrm{L}$ of MTT in an incubator for about $4 \mathrm{~h}$. The medium was thrown away and replaced by $100 \mathrm{~mL}$ DMSO. The O.D. value was read at 570/630 nm using an enzyme labeling instrument.

\subsection{Hoechst 333258 assay}

NCI-H460 cells $\left(2 \times 10^{6}\right.$ cells $)$ were seeded in six-well tissue culture plates and exposed to compound I-11 $(10 \mu \mathrm{M})$ for different times. The cells were fixed in $4 \%$ paraformaldehyde for $10 \mathrm{~min}$, after which the medium was discarded. The cells were then washed twice with cold PBS and incubated with $0.5 \mathrm{~mL}$ of Hoechst 33258 (Beyotime, China) in the dark for 5 min. After 5 min incubation, the cells were washed twice with cold PBS and the results were analyzed using a Nikon ECLIPSETE2000-S fluorescence microscope using $350 \mathrm{~nm}$ excitation and $460 \mathrm{~nm}$ emissions.

\subsection{Determination of mitochondrial membrane potential}

The JC-1 probe (Beyotime, Haimen, China) was employed to measure mitochondrial depolarization in NCI-H460 cells. Briefly, NCI-H460 cells were seeded at the density of $2 \times 10^{6}$ cells $\mathrm{mL}^{-1}$ of the DMEM medium with $10 \%$ FBS on 6 -well plates to the final volume of $2 \mathrm{~mL}$. The plates were incubated overnight and then treated with compound I-11 $(10 \mu \mathrm{M})$ for different times. The JC- 1 probe was added 20 min after replacing with fresh medium. Cells were collected at $2000 \mathrm{rpm}$, rinsed twice 
with cold PBS and the mitochondrial membrane potential was analysed in the FL-1 channel by flow cytometry (FACS Aria II; BD, USA).

\subsection{Apoptosis analysis}

NCI-H460 cells were seeded at the density of $2 \times 10^{6}$ cells $\mathrm{mL}^{-1}$ of the DMEM medium with $10 \%$ FBS on 6-well plates to the final volume of $2 \mathrm{~mL}$. The plates were incubated overnight and then treated with different concentrations of compound I-11 for $24 \mathrm{~h}$. Briefly, after treatment with compound I-11 for $24 \mathrm{~h}$, cells were collected and washed twice with PBS, then resuspended in Binding Buffer (0.1 M Hepes/NaOH (pH 7.4), 1.4 M NaCl, $25 \mathrm{mM}$ $\mathrm{CaCl}_{2}$ ) at a concentration of $1 \times 10^{6}$ cells $\mathrm{mL}^{-1}$. The cells were subjected to $5 \mu \mathrm{L}$ of FITC Annexin V and $5 \mu \mathrm{L}$ of propidium iodide (PI) staining using the Annexin-V FITC apoptosis kit (BD, Pharmingen), followed by the transfer of $100 \mu \mathrm{L}$ of the solution to a $5 \mathrm{~mL}$ culture tube and incubating for $30 \mathrm{~min}$ in the dark at RT $\left(25^{\circ} \mathrm{C}\right)$. The apoptosis ratio was quantified by system software (CellQuest; BD Biosciences).

\subsection{Cell cycle analysis}

The NCI-H460 cell line was treated with different concentrations of compound I-11. After $48 \mathrm{~h}$ of incubation, cells were washed twice with ice-cold PBS, fixed and permeabilized with ice-cold $70 \%$ ethanol at $-20{ }^{\circ} \mathrm{C}$ overnight. The cells were treated with $100 \mu \mathrm{g} \mathrm{mL}{ }^{-1}$ RNase A at $37{ }^{\circ} \mathrm{C}$ for $30 \mathrm{~min}$ after washing with ice-cold PBS, and finally stained with $1 \mathrm{mg} \mathrm{mL}^{-1}$ of propidium iodide (PI) (BD, Pharmingen) in the dark at $4{ }^{\circ} \mathrm{C}$ for $30 \mathrm{~min}$. Analysis was performed with the system software (Cell Quest; BD Biosciences).

\subsection{ROS assay}

NCI-H460 cells were seeded into six-well plates and subjected to various treatments. Cells were collected and washed with PBS twice, then resuspended in $10 \mathrm{mM}$ of DCFH-DA (Beyotime, Haimen, China) dissolved in cell free medium at $37{ }^{\circ} \mathrm{C}$ for $30 \mathrm{~min}$ in the dark, and then washed three times with PBS. Cellular fluorescence was quantified by flow cytometry at an excitation of $485 \mathrm{~nm}$ and an emission of $538 \mathrm{~nm}$.

\subsection{Calcium analysis}

NCI-H460 cells were seeded into six-well plates and subjected to various treatments. The cells were collected and washed with PBS twice. Intracellular free $\mathrm{Ca}^{2+}$ levels in NCI-H460 cells were detected using the $\mathrm{Ca}^{2+}$ specific fluorescent probe, Fluo-3/AM (Beyotime, Haimen, China), for 40 min at $37^{\circ} \mathrm{C}$ in PBS buffer. After loading with the Fluo-3 dye, cells were washed with PBS solution and cellular fluorescence was quantified using flow cytometry at wavelength of $515 \mathrm{~nm}$.

\subsection{Western blot}

Total cell lysates from cultured NCI-H460 cells after compound I-11 treatments, as mentioned earlier, were obtained by lysing the cells in ice-cold RIPA buffer with protease and phosphatase inhibitor, and storing at $-20{ }^{\circ} \mathrm{C}$ for future use. The protein concentrations were quantified by the Bradford method (BIORAD) using Multimode varioscan instrument (Thermo Fisher Scientifics). Equal amounts of protein per lane were applied in $12 \%$ SDS polyacrylamide gel for electrophoresis and transferred to the polyvinylidine difluoride (PVDF) membrane (Amersham Biosciences). After the membrane was blocked at room temperature for $2 \mathrm{~h}$ in blocking solution, primary antibody was added and incubated at $4{ }^{\circ} \mathrm{C}$ overnight. Caspase-9, caspase-3 caspase-12, calpain, caspase-4, CHOP, GRP78, p-PERK and peIF $2 \alpha$ antibodies were purchased from Imgenex, USA. After three TBST washes, the membrane was incubated with the corresponding horseradish peroxidase-labeled secondary antibody $(1: 2000)$ (Santa Cruz) at room temperature for $1 \mathrm{~h}$. Membranes were washed with TBST three times for $15 \mathrm{~min}$ and the protein blots were detected with chemiluminescence reagent (Thermo Fischer Scientifics Ltd.). The X-ray films were developed with developer and fixed with fixer solution.

\section{Statistics}

The data were processed by the Student's $t$-test, with the significance level $P \leq 0.05$, using SPSS.

\section{Acknowledgements}

This study was supported by the National Natural Science Foundation of China (No. 8126047221362002 and 21431001), Special Research Found for the Doctoral Program of Higher Education (No. 20134504110002), State Key Laboratory for Chemistry and Molecular Engineering of Medicinal Resources, Ministry of Science and Technology of China (CMEMR2016B06), Project Funded by the Priority Academic Program Development of Jiangsu Higher Education Institutions (No. 1107047002).

\section{References}

1 (a) F. F. Tian, P. Zhou and Z. L. Li, J. Mol. Struct., 2007, 830, 106; (b) T. Day and S. A. Greenfield, Exp. Brain Res., 2004, 155, 500.

2 Z. Qi, R. Verma, C. Gehring, Y. Yamaguchi, Y. Zhao, C. A. Ryan and G. A. Berkowitz, Proc. Natl. Acad. Sci. U. S. A., 2010, 107, 21193.

3 A. Thompson, W. Liu, E. Chun, V. Katritch, H. Wu, E. Vardy, X.-P. Huang, C. Trapella, R. Guerrini, G. Calo, B. L. Roth, V. Cherezov and R. C. Stevens, Nature, 2012, 485, 395.

4 K. Naka, Y. Jomen, K. Ishihara, J. Kim, T. Ishimoto, E.-J. Bae, R. P. Mohney, S. M. Stirdivant, H. Oshima, M. Oshima, D.-W. Kim, H. Nakauchi, Y. Takihara, Y. Kato, A. Ooshima and S.-J. Kim, Nat. Commun., 2015, 6, 8039.

5 R. C. Kane, R. Dagher, A. Farrell, C. W. Ko, R. Sridhara, R. Justice and R. Pazdur, Clin. Cancer Res., 2007, 13, 5291.

6 K. M. Kortuem and A. K. Stewart, Blood, 2013, 121, 893.

7 U. Vaishampayan, M. Glode, W. Du, A. Kraft, G. Hudes, J. Wright and M. Hussain, Clin. Cancer Res., 2000, 6, 4205.

8 E. Kupperman, E. C. Lee, Y. Cao, B. Bannerman, M. Fitzgerald, A. Berger, J. Yu, Y. Yang, P. Hales, 
F. Bruzzese, J. Liu, J. Blank, K. Garcia, C. Tsu, L. Dick, P. Fleming, L. Yu, M. Manfredi, M. Rolfe and J. Bolen, Cancer Res., 2010, 70, 1970.

9 H. A. Lim, M. J. Y. Ang, J. Joy, A. Poulsen, W. Wu, S. C. Ching, J. Hill and C. S. B. Chia, Eur. J. Med. Chem., 2013, 62, 199.

10 H. Chen, C. Han, J. Wu, X. Liu, Y. Zhan, J. Chen, Y. Chen, R. Gu, L. Zhang, S. Chen, J. Jia, X. Zhen, L. T. Zheng and B. Jiang, ACS Chem. Neurosci., 2016, 7, 305.

11 X.-C. Huang, L. Jin, M. Wang, D. Liang, Z.-F. Chen, Y. Zhang, Y.-M. Pan and H.-S. Wang, Eur. J. Med. Chem., 2015, 89, 370. 12 J. D. Leverson, H. Zhang, J. Chen, S. K. Tahir, D. C. Phillips, J. Xue, P. Nimmer, S. Jin, M. Smith, Y. Xiao, P. Kovar, A. Tanaka, M. Bruncko, G. S. Sheppard, L. Wang, S. Gierke, L. Kategaya, D. J. Anderson, C. Wong, J. EasthamAnderson, M. J. C. Ludlam, D. Sampath, W. J. Fairbrother, I. Wertz, S. H. Rosenberg, C. Tse, S. W. Elmore and A. J. Souers, Cell Death Dis., 2015, 6, e1590.

13 G. Silveira-Dorta, V. S. Martín and J. M. Padrón, Amino Acids, 2015, 47, 1527.

14 B. Iovine, F. Guardia, C. Irace and M. A. Bevilacqua, Biochimie, 2016, 127, 196.

15 Y. Shen, J. Yang, J. Li, X. Shi, L. Ouyang, Y. Tian and J. Lu, PLoS One, 2014, 9, e104632.

16 M. Pandurangan, G. Enkhtaivan and D. H. Kim, J. Mol. Recognit., 2016, 29, 426.

17 J.-Z. Liu, B.-A. Song, H.-T. Fan, P. S. Bhadury, W.-T. Wan, S. Yang, W. Xu, J. Wu, L.-H. Jin, X. Wei, D.-Y. Hu and S. Zeng, Eur. J. Med. Chem., 2010, 45, 5108.

18 R. Ettari, C. Bonaccorso, N. Micale, C. Heindl, T. Schirmeister, M. L. Calabro, S. Grasso and M. Zappal, ChemMedChem, 2011, 6, 1228.

19 S. K. Sharma, Y. Wu, N. Steinbergs, M. L. Crowley, A. S. Hanson, R. A. Casero Jr and P. M. Woster, J. Med. Chem., 2010, 53, 5197.

20 C. J. Hsiao, L. Tsia-Kun, Y. L. Chan, L. W. Hsin, C. H. Liao, C. H. Lee, P. C. Lyu and J. H. Guh, Biochem. Pharmacol., 2008, 75, 847.

21 S. Zitzmann, V. Ehemann and M. Schwab, Cancer Res., 2002, 62, 5139.

22 C. Monneret, Eur. J. Med. Chem., 2001, 36, 483.

23 D. Ravel, V. Dubois, J. Quinonero, F. Meyer-Losic, J. Delord, P. Rochaix, C. Nicolazzi, F. Ribes, C. Mazerolles, E. Assouly, K. Vialatte, I. Hor, J. Kearsey and A. Trouet, Clin. Cancer Res., 2008, 15, 1258.
24 K. Sidoryk, M. Switalska, J. Wietrzyk, A. Jaromin, M. PiętkaOttlik, P. Cmoch, J. Zagrodzka, W. Szczepek, Ł. Kaczmarek and W. Peczynska-Czoch, J. Med. Chem., 2012, 55, 5077.

25 S. Shaaban, F. Sasse, T. Burkholz and C. Jacob, Bioorg. Med. Chem., 2014, 22, 3610.

26 B. Krust, D. E. Khoury, C. Soundaramourty, I. Nondier and A. G. Hovanessian, Biochimie, 2011, 93, 426.

27 H. Q. Li, P. C. Lv, T. Yan and H. L. Zhu, Anti-Cancer Agents Med. Chem., 2009, 9, 471-480.

28 S. Saeed, N. Rashid, P. G. Jones, M. Ali and R. Hussain, Eur. J. Med. Chem., 2010, 45, 1323.

29 S. Y. Abbas, M. A. M. S. El-Sharief, W. M. Basyouni, I. M. I. Fakhr and E. W. El-Gammal, Eur. J. Med. Chem., 2013, 64, 111.

30 E. Tatar, S. Karakuş, Ş. G. Küçükgüzel, S. Ö. Okullu, N. Ünübol, T. Kocagöz, E. D. Clercq, G. Andrei, R. Snoeck, C. Pannecouque, S. Kalaycı, F. Şahin, D. Sriram, P. Yogeeswari and İ. Küçükgüzel, Biol. Pharm. Bull., 2016, 39, 502.

31 M.-H. Chen, Z. Chen, B.-A. Song, P. S. Bhadury, S. Yang, X.-J. Cai, D.-Y. Hu, W. Xue and S. Zeng, J. Agric. Food Chem., 2009, 57, 1383.

32 P. P. Dixit, V. J. Patil, P. S. Nair, S. Jain, N. Sinha and S. K. Arora, Eur. J. Med. Chem., 2006, 41, 423.

33 X. C. Huang, R. Z. Huang, Z. X. Liao, Y. M. Pan, S. H. Gou and H. S. Wang, Eur. J. Med. Chem., 2016, 108, 381.

34 S. Achilefu, H. N. Jimenez, R. B. Dorshow, J. E. Bugaj, E. G. Webb, R. R. Wilhelm, R. Rajagopalan, J. Johler and J. L. Erion, J. Med. Chem., 2002, 45, 2003.

35 C. Alemán, J. Phys. Chem. A, 2001, 105, 6717.

36 A. G. Doyle and E. N. Jacobsen, Chem. Rev., 2007, 107, 5713. 37 P. Liu, C. Li, J. Zhang and X. Xu, Synth. Commun., 2013, 43, 3342.

38 J. K. Randal and D. M. Jyoti, Biochim. Biophys. Acta, Mol. Cell Res., 2014, 1843, 2233-2239.

39 G. Nowak, J. Biol. Chem., 2002, 277, 43377.

40 H. U. Simon, A. H. Yehia and F. L. Schaffer, Apoptosis, 2000, 5, 415 .

41 J. M. David and O. Sten, J. Leukocyte Biol., 1996, 59, 775.

42 S. Orrenius, B. Zhivotovsky and P. Nicotera, Nat. Rev. Mol. Cell Biol., 2003, 4, 552.

43 B. V. S. Reddy, K. Bhavani, A. Raju and J. S. Yadav, Tetrahedron: Asymmetry, 2011, 22, 881. 